Published in Biotechnology Advances (2015) 33:25-40.

\title{
Laccase engineering: from rational design to directed evolution
}

\author{
Diana M. Mate ${ }^{1}$ and Miguel Alcalde $2^{*}$
}

${ }^{1}$ DWI-Leibniz-Institute for Interactive Materials, Forckenbeckstraße 50, 52056, Aachen, Germany.

${ }^{2}$ Department of Biocatalysis, Institute of Catalysis, CSIC, Cantoblanco, 28049 Madrid, Spain.

*Corresponding author: Miguel Alcalde, Department of Biocatalysis, Institute of Catalysis, CSIC, Cantoblanco, 28049 Madrid, Spain. malcalde@icp.csic.es. 


\section{Abstract}

Laccases are multicopper oxidoreductases considered by many in the biotechonology field as the ultimate "green catalysts". This is mainly due to their broad substrate specificity and relative autonomy (they use molecular oxygen from air as an electron acceptor and they only produce water as byproduct), making them suitable for a wide array of applications: biofuel production, bioremediation, organic synthesis, pulp biobleaching, textiles, the beverage and food industries, biosensor and biofuel cell development. Since the beginning of the $21^{\text {st }}$ century, specific features of bacterial and fungal laccases have been exhaustively adapted in order to reach the industrial demands for high catalytic activity and stability in conjunction with reduced production cost. Among the goals established for laccase engineering, heterologous functional expression, improved activity and thermostability, tolerance to non-natural media (organic solvents, ionic liquids, physiological fluids) and resistance to different types of inhibitors are all challenges that have been met, while obtaining a more comprehensive understanding of laccase structure-function relationships. In this review we examine the most significant advances in this exciting research area in which rational, semi-rational and directed evolution approaches have been employed to ultimately convert laccases into high value-added biocatalysts.

Keywords: fungal laccase, bacterial laccase, functional expression, redox potential, rational design, directed evolution, saturation mutagenesis, laccase chimeras, DNA recombination.

\section{Introduction}

Laccases (EC 1.10.3.2, benzenediol:oxygen oxidoreductases) catalyse the oxidation of a wide array of compounds coupled with the four-electron reduction of oxygen to water (Morozova et al., 2007a). They belong to the multicopper oxidase family, which also comprises ceruloplasmin, ascorbate oxidase, bilirubin oxidases and ferroxidases (Solomon et al., 1996). These enzymes contain four copper atoms: one paramagnetic type 1 copper (T1 $\mathrm{Cu}$ ) that is responsible for their characteristic blue colour and where the oxidation of the reducing substrate occurs; one type 2 copper (T2 Cu); and two type 3 coppers (T3 Cu) that conform a trinuclear cluster in which molecular oxygen is reduced to two molecules of water (Mot and SilaghiDumitrescu, 2012) (Fig. 1).

Since a laccase was first extracted from the exudate of the Japanese lacquer tree Toxicodendron vernicifluum in the late nineteenth century (Yoshida, 1883), these enzymes have been identified in more than 20 bacterial species (Santhanam et al., 2011), in several higher plant species (Mayer and Staples, 2002) and in lichens (Laufer et al., 2009). Moreover, polyphenol oxidases with laccase-like activity have also been described in insect cuticles (Lang et al., 2012), in oysters (Luna-Acosta et al., 2010) and in metagenomic libraries of bovine rumen (Beloqui et al., 2006). However, 
laccases are particularly abundant in fungi, having been found in almost all wood-rotting fungi analysed to date (Brijwani et al., 2010). While bacterial laccases are intracellular or periplasmic enzymes, fungal laccases are typically extracellular proteins that show different glycosylation degrees.

Laccases play diverse biological roles that are determined by their origin and the life stage of the organism that produces them. In bacteria they participate in morphogenesis, pigmentation, oxidation of toxic compounds, and protection against ultraviolet radiation and oxidizing agents (Singh et al., 2011). In addition, plant laccases are involved in wound responses and lignin polymerization (Mayer and Staples, 2002), while the polyphenol oxidases with laccase activity discovered in insect cuticles participate in the sclerotisation (Miessner et al., 1991). In fungi, diverse functions are fulfilled by laccases, including morphogenesis, stress defence, fungal plant-pathogen/host interactions and lignin degradation (Alcalde, 2007).

The substrate range of laccases is very broad as they can oxidize aromatic compounds (ortho- and para-diphenols, methoxysubstituted phenols, diamines, benzenethiols), metal ions $\left(\mathrm{Mn}^{2+}\right)$, organometallic compounds (e.g. $\left.\left[\mathrm{W}(\mathrm{CN})_{8}\right]^{4-},[\mathrm{Fe}(\mathrm{EDTA})]^{2-}\right)$, organic redox compounds (e.g. 2,2'-azino-bis(3-ethylbenzothiazoline-6-sulphonic acid), ABTS; 1hydroxybenzotriazole, HBT) and the iodide anion (Morozova et al., 2007b; $\mathrm{Xu}, 1996)$. Furthermore, in the presence of both natural and synthetic redox mediators, the catalytic activity of these enzymes may be expanded to non-phenolic substrates that are very recalcitrant and hardly oxidized by laccase alone (e.g. polycyclic aromatic hydrocarbons (PAH), polychlorinated biphenyls, azo-dyes or organophosphate pesticides) (Cañas and Camarero, 2010).

From an electrochemical viewpoint and based on the analysis of their molecular structures, these enzymes are classified into three different groups according to the redox potential of the T1 site $\left(\mathrm{E}^{0}{ }_{\mathrm{T} 1}^{\prime}\right)$ : low-, medium-, and high-redox potential laccases (Mot and Silaghi-Dumitrescu, 2012) (Table 1). The $\mathrm{E}^{0^{\prime}}{ }_{\mathrm{T} 1}$ of laccases is not determined by a single structural feature but it is rather the result of the combination of various factors, such as copper-ligand interactions, the effects of desolvation around the T1 site, the intermolecular electrostatic interactions, and the restrictions in protein folding (Li et al., 2004). Bacterial and plant laccases constitute the group of low-redox potential laccases, with an $\mathrm{E}^{0^{\prime}}{ }^{\prime} 1$ below $+460 \mathrm{mV}$ vs. NHE (Normal Hydrogen Electrode) and a Met residue as the T1 $\mathrm{Cu}$ axial ligand. Fungal laccases fall into the medium- and high-redox potential classes. The group of medium-redox potential laccases includes enzymes from ascomycetes and basidiomycetes fungi, with an $\mathrm{E}^{0}{ }^{\prime}$ 11 ranging from +460 to $+710 \mathrm{mV}$ vs. NHE, and typically with a Leu as the non-coordinating axial ligand. High-redox potential laccases (HRPL) are mainly produced by basidiomycete white-rot fungi, with an $\mathrm{E}^{\mathrm{O}^{\prime}} \mathrm{T1}$ ranging from +730 to $+790 \mathrm{mV}$ vs. NHE, and with a Phe as the non-coordinating axial ligand. This latter group is the most relevant for distinct industrial applications, since their 
$\mathrm{E}^{\mathrm{O}^{\prime}}$ T1 allows HRPL to oxidise a much wider range of substrates than their low- and medium-redox potential counterparts (Rodgers et al., 2009).

There are many potential applications for laccases in different industrial and technological sectors, the most prominent of which include:

- Food industry: in beverage processing (wine, fruit juice and beer), in the determination of ascorbic acid and in the gelation of sugar beet pectin (Osma et al., 2010).

- Paper industry: in the chlorine-free bleaching of paper pulp and in effluent treatment (Couto and Herrera, 2006).

- Textile industry: in fibre modification, fabric bleaching and in the degradation of wastewater dyes (Couto and Herrera, 2006).

- Furniture and construction industry: in the cross-linking of ligninbased materials to obtain medium density fibreboards (Alcalde, 2007).

- Paint industry: laccase-mediator systems for the drying of alkyd resins widely employed in paints and coatings (Greimel et al., 2013).

- Organic chemistry: in the oxidative coupling of radical intermediates to obtain antitumor compounds (e.g. actinocin or vinblastine), cyclosporin derivatives (e.g. cyclosporin A), hormones (e.g. $\beta$-estradiol) and phytoalexins (e.g. resveratrol), (Kunamneni et al., 2008a) as well as in the enzymatic derivatization of amino acids such as Ltryptophane, L-phenylalanine or L-lysine (Mogharabi and Faramarzi, 2014).

- Biofuels: to remove phenolic compounds that inhibit the fermentation of the sugars present in the hydrolysate of lignocellulosic materials (Kudanga and Le Roes-Hill, 2014).

- Soil bioremediation: degradation of 2,4,6-trinitrotoluene (TNT) and PAH (Couto and Herrera, 2006).

- Cosmetics industry: in the preparation of hair dyes and skin lightening preparations (Couto and Herrera, 2006).

- Biomedical industry: laccase immobilization in strips or bandages to be used for the diagnosis of fungal infections (Schneider et al., 2012).

- Nanobiotechnology: in the development of biofuel cells and biosensors to detect different compounds and metabolites (Kunamneni et al., 2008b).

Laccases have been reviewed extensively in recent years and the reader is referred to other reviews about these enzymes, addressing general aspects (Alcalde, 2007; Gianfreda et al., 1999; Giardina et al. 2010), industrial applications (Kunamneni et al., 2008a), heterologous production (Piscitelli et al., 2010), laccases in organic synthesis (Kunamneni et al., 2008a; Mogharabi and Faramarzi, 2014; Riva 2006), laccase mediator systems (Call and Mucke, 1997; Morozova et al., 2007b; Cañas and Camarero, 2010), laccase design (Maté et al., 2011; Rodgers et al., 2009), laccase electronic pathways (Wherland et al., 2014), fungal laccases (Baldrian et al., 2006) and bacterial laccases (Santhanam et al., 2011; Singh et al., 2011). 
In the current review, we provide a comprehensive update of all the studies focused on the production and engineering of this versatile group of oxidoreductases. First of all, the heterologous laccase expression systems reported to date will be reviewed and thereafter, we will focus on laccase engineering by rational approaches. We will then address the semi-rational strategies employed to improve these enzymes involving saturation mutagenesis of multiple or specific residues in the laccase and finally, we will analyse the most recent advances in directed laccase evolution combined with hybrid approaches. For the sake of clarity, the studies on bacterial and fungal laccases are described independently due to their different properties in terms of redox potential, thermostability, $\mathrm{pH}$ activity profiles and halide inhibition.

\section{Heterologous laccase expression}

The biotechnological application of laccases requires industrial-scale production of active and stable enzymes. However, achieving this goal is generally impeded by poor expression in homologous microorganisms, as well as by the growth conditions. This hurdle has been addressed in two different ways: i) by optimizing the components of the culture medium in order to increase homologous expression (e.g. adjusting the presence of metal ions, aromatic compounds derived from lignin, or the nitrogen and carbon sources) (Collins and Dobson, 1997; Lee et al., 1999; Terrón et al., 2004); and ii) by enhancing heterologous expression through the use of strong promoters, multicopy vectors and signal peptides capable of directing laccase secretion to the extracellular medium, as well as by directed evolution (see below). Indeed, with the exception of the homologous overexpression of the laccase from Pycnoporus cinnabarinus, which augmented laccase secretion to $1.2 \mathrm{~g} / \mathrm{L}$ (Alves et al., 2004), most effort has focused on the development of heterologous expression systems (Kunamneni et al., 2008a, Piscitelli et al., 2010).

The heterologous expression of laccases has been achieved in different bacterial species (Escherichia coli and Streptomyces lividans), plants (Arabidopsis thaliana, Lycopersicon esculentum, Nicotiana tabacum, Oryza sativa and Zea mays), yeast (Kluyveromyces lactis, Pichia methanolica, Pichia pastoris, Saccharomyces cerevisiae and Yarrowia lipolytica) and filamentous fungi (Aspergillus nidulans, Aspergillus niger, Aspergillus oryzae, Aspergillus sojae, Penicillium canescens and Trichoderma reesei). In particular, fungal laccases have been expressed in yeast, filamentous fungi and plants. Moreover, functional expression of the laccase from the ligninolytic fungus Cyathus bulleri was recently described in $E$. coli, becoming the first fungal laccase expressed in a bacterial host (Garg et al., 2008). Tables 2, $\mathbf{3}$ and $\mathbf{4}$ give a complete list of all heterologously expressed laccases to date, both from bacterial (Table 2) and fungal origin (Tables 3 and $\mathbf{4}$ ).

In many cases, the expression of fungal laccases can be achieved by replacing the native signal peptide with the signal sequence of proteins that 
are secreted in large amounts by the host microorganism. Thus, heterologous production of fungal laccases has been described using different signal peptides, among them: the a factor prepro-leader and the signal peptide of the invertase from $S$. cerevisiae; the signal sequence of the XPR2 alkaline protease from $Y$. lipolytica; the leader of $A$. niger glucoamylase; the leader of the $\beta$-galactosidase from $P$. canescens; the signal peptide of glutelin $\mathrm{B} 1$ from $O$. sativa; the signal sequence of the cellobiosehydrolase 1 from $T$. reesei and the a-amylase leader from Hordeum vulgare. The use of filamentous fungi as expression systems has led to the strongest heterologous production of fungal laccases. T. reesei secretes up to $920 \mathrm{mg} / \mathrm{L}$ of Melanocarpus albomyces laccase (Kiiskinen et al., 2004), and between 800 and $1000 \mathrm{mg} / \mathrm{L}$ of Trametes versicolor laccase (Baker and White, 2001), while A. niger produces $840 \mathrm{mg} / \mathrm{L}$ of the LAC3 laccase from Trametes sp. C30 (Mekmouche et al., 2014) (Table 4). However, optimization of gene expression through different mutagenic techniques (especially directed evolution) is difficult to achieve in filamentous fungi (Robert et al., 2011). For this reason, the cloning and expression of fungal laccases is often carried out in yeast, since they can grow as individual colonies, they do not produce endogenous laccases and the recombinant products are directly secreted into the extracellular medium facilitating the detection of laccase activity without complex lysis steps. Among yeast species, S. cerevisiae and $P$. pastoris are the most commonly used for laccase production, since there are a wide variety of molecular biology techniques that facilitate their manipulation (e.g. replicative plasmids, constitutive or inducible promoters and simple transformation protocols) and they are easily cultured (Piscitelli et al., 2010).

\section{Laccase engineering}

\subsection{Rational approaches}

Site-directed mutagenesis of specific residues chosen on the basis of prior structural information is a strategy that has been commonly used to study laccase structure-function relationships (Table 5).

i) Bacterial laccases: Two different site-directed mutagenesis studies have been carried out using the endospore-coat laccase CotA from Bacillus subtilis (Durão et al., 2006, 2008). The main goal was to evaluate how the redox potential and catalytic efficiency of this enzyme are influenced by modifying residues involved in the coordination and stabilization of the T1 $\mathrm{Cu}$ site. Initially, the weakly coordinating Met of the $\mathrm{T} 1 \mathrm{Cu}$ was substituted with non-coordinating Leu and Phe residues (Durão et al., 2006). The geometry of the T1 copper centre in these two variants (M502L and M502F) was similar to that of the wild-type, yet both the redox potential and the catalytic activity were significantly altered. The $\mathrm{E}^{0}{ }_{\mathrm{T} 1}$ of the two mutants increased by around $100 \mathrm{mV}$ with respect to that of the native laccase but the $k_{\text {cat }}$ was negatively affected. The M502L mutant displayed a 2 to 4 -fold decrease in the $k_{\text {cat }}$ for phenolic and non-phenolic substrates while in the 
M502F variant the effect was even more pronounced: the $k_{\text {cat }}$ values were 10 to 1,840 -fold lower to those of the wild-type enzyme. However, it was not found a direct correlation between the enhancement in the redox potentials and the decrease in activity. Subsequently, two hydrophobic residues in the vicinity of the $\mathrm{T} 1 \mathrm{Cu}$ (Leu386 and Ile494) were mutated to Ala, generating two mutants with strongly altered spectral properties of the copper centres compared to the wild-type (Durão et al., 2008). Additionally, these mutants showed a decrease in the $\mathrm{E}^{0}$ 'T1 (approx. 60 and $100 \mathrm{mV}$ for L386A and I494A mutants, respectively). According to the crystal structures of these two site-directed mutants, the replacement of hydrophobic residues by Ala in the neighbourhood of the $\mathrm{T} 1 \mathrm{Cu}$ increased the solvent accessibility affecting the $\mathrm{E}^{0}{ }^{\prime} \mathrm{T} 1$.

Laccase from Bacillus sp. HR03 was subjected to rational design in order to increase its thermal stability (Mollania et al., 2011). The key Glu188 residue -located in the connecting loop between domains 1 and 2- was replaced by one hydrophobic (Ala) and two positive (Lys and Arg) residues. These three variants had enhanced thermal stability as well as thermal activation with respect to the wild-type. The most stable mutant (E188K) displayed a 3 -fold improvement in thermal activation and a $5^{\circ} \mathrm{C}$ higher $\mathrm{T}_{50}$ than that of the wild-type, while its $K_{\mathrm{m}}$ for syringaldazine was reduced 1.4fold. This increase in thermal stability and substrate affinity might suggest an enhanced robustness of the laccase structure. Similarly, the tolerance of this laccase to organic solvents was improved by directed mutagenesis when Glu188 was substituted with non-polar (Ala, Ile, Leu and Val) and positively charged (Lys and Arg) residues (Rasekh et al., 2014). Although all variants had higher $\mathrm{C}_{50}$ values -the organic solvent concentration at which the enzyme retains $50 \%$ of its activity- than the native laccase, mutants containing non-polar substitutions exhibited the most pronounced increase in $\mathrm{C}_{50}$, as well as the highest decrease in the thermoinactivation rate in the presence of organic solvents.

The laccase CueO from $E$. coli has been also subjected to site-directed mutagenesis. The Met axial ligand of the T1 center (Met510) was replaced by: i) Leu, to generate the three-coordinated $\mathrm{T} 1 \mathrm{Cu}$ typical of fungal laccases with medium-redox potential (see Table 1); ii) Ala and Thr, to evaluate the effect of bulkiness and polarity of the side chain on the redox potential; and iii) $\mathrm{Gln}$, to obtain a $\mathrm{T} 1 \mathrm{Cu}$ site with lower redox potential found in other blue copper containing proteins, such as stellacyanin or mavicyanin (Kurose et al., 2009). Compared with the wild-type laccase, the mutants displayed significant changes in the activity and $\mathrm{E}^{0}{ }^{\prime} \mathrm{T} 1$, which were in correlation with the characteristics of their circular dichroism, absorption and electron paramagnetic resonance spectra. More recently, CueO variants with single, double and triple mutations in the first and second coordination spheres of the $\mathrm{T} 1 \mathrm{Cu}$ have been studied (Kataoka et al., 2013). Specifically, four single mutants (D439A, P444A, M510L and M510Q), five double mutants (D439A/P444A, D439A/M510L, D439A/M510Q, P444A/M510L and P444A/M510Q) and two triple variants (D439A/P444A/M510L and D439A/P444A/M510Q) were evaluated. These mutants showed catalytic efficiencies for ABTS up to 140-fold higher than 
the wild-type, while their $\mathrm{E}^{0}{ }_{\mathrm{T} 1}$ were between $150 \mathrm{mV}$ lower and $100 \mathrm{mV}$ higher than that of the native enzyme.

In the small laccase SLAC from Streptomyces coelicolor, the Tyr108 located at the interface of two subunits of the trimeric form of the enzyme was replaced by Phe and Ala to study the role of this residue in the catalytic mechanism (Gupta et al., 2012). The mutation reduced $\sim 2.5$-fold the turnover numbers without affecting the catalytic efficiency. Lately, new studies have focused on redesigning the substrate binding pocket of SLAC for phenolic compounds by replacing residues close to the T1 site that seem to be involved in binding the reducing substrate (Toscano et al., 2013). In particular, five single (M168G, M168A, Y199W, M266A and M266W) and two double mutants (M168G/M266A and M168G/M266W) were characterized. All the variants had improved catalytic efficiencies for 2,6dimethoxyphenol (DMP) compared to the wild-type, together with better mediator-assisted decolorization of indigo carmine. This laccase has also been studied rationally to reveal the residues that are important for activity, 10 of these being His residues that coordinate the copper sites (Sherif et al., 2013).

Recently, the two-domain laccase Ss11 from Streptomyces sviceus was subjected to site-directed mutagenesis (several Met residues located in the putative substrate-binding site of the enzyme were replaced by Leu) (Gunne et al., 2014). Specifically, the mutagenesis studies involved the axial Met ligand of the T1 Cu (Met295) as well as the three Met located nearby the T1 site (Met195, Met220 and Met293). Moreover, a truncated mutant without the 17 residues corresponding to the $\mathrm{C}$-terminus of the laccase was evaluated. All the variants showed higher redox potentials (ranging from 16 and $81 \mathrm{mV}$ over the wild-type). Among them, the strongest effect was observed in the $\mathrm{M} 295 \mathrm{~L}$ mutant whose $\mathrm{E}^{0}$ T1 was risen up to $+456 \mathrm{mV}$ but at the cost of jeopardizing the kinetic parameters highlighting the delicate balance between redox potential and substrate binding.

ii) Fungal laccases: The late 1990's saw the first attempts to engineer fungal laccases by rational approaches when several residues surrounding the catalytic copper centres of laccases from Myceliopthora thermophila, Rhizoctonia solani and Trametes villosa were subjected to site-directed mutagenesis to determine the parameters responsible for the catalytic activity and redox potential (Palmer et al., 2003; Xu et al., 1998, Xu et al., 1999). First, four different mutants of the medium-redox potential laccases from $R$. solani and $M$. thermophila were designed, carrying either a single or a triple mutation in a highly conserved pentapeptide which corresponds to the sequence ${ }_{512} \mathrm{HLHMGM}_{517}$ of the Zucchini ascorbate oxidase (zAO) (Xu et al., 1998). More specifically, the L470F and L466V/E467S/A468G variants from $R$. solani laccase and the L513F and V509L/S510E/G511A mutants of $M$. thermophila were evaluated. The single mutations neither significantly alter the spectro-electrochemical properties (redox potential, cooper geometry), nor the biochemical ones (kinetic parameters, $\mathrm{pH}$ activity profiles, fluoride inhibition). By contrast, the triple mutant showed a 
different behaviour: shifted $\mathrm{pH}$ activity profiles, lower $k_{\text {cat }}$ values for both syringaldazine and ABTS, and higher tolerance against inhibition by fluoride ions at low $\mathrm{pH}$ values. In a later study, $\mathrm{Xu}$ and co-workers reported the mutagenesis of two specific residues of the HRPL from T. villosa: i) the Phe463 -corresponding to the $\mathrm{Cu}$ axial Met ligand in zAO- was replaced by a non-coordinating Leu -mimicking medium-redox potential laccases(Table 1) or by Met; and ii) the Ala461 -near the $\mathrm{T} 1 \mathrm{Cu}$ site and corresponding to the Met515 in the zAO- by Glu (Xu et al., 1999). The F463L and A461E mutations hardly modified the general features of the enzyme in terms of redox potentials, EPR and UV-visible spectra, kinetic values and $\mathrm{pH}$-activity profiles. On the contrary, the F463M did showed several significant changes: a decrease of $100 \mathrm{mV}$ in the $\mathrm{E}^{{ }^{\prime}}{ }_{\mathrm{T} 1}$, altered EPR and UV-visible spectra, and an increase in the $k_{\text {cat }}$ and $K_{\mathrm{m}}$ for syringaldazine and ABTS shifting the optimum $\mathrm{pH}$ value for oxidation of syringaldazine (but not for ABTS). Finally, the electronic structure of the L513H variant of the $M$. thermophila laccase was analysed by spectroscopic methods and density functional estimations (Palmer et al., 2003). This mutation gave rise to significant alterations of the structural arrangement of the $\mathrm{T} 1 \mathrm{Cu}$, which even switched from blue to green colour at the resting oxidized state.

More recently, structure-function studies were performed on the laccase from the ascomycete Melanocarpus albomyces (MaL) to study the catalysis on phenolic and non-phenolic substrates (Kallio et al., 2009). Based on the MaL crystal structure, a conserved carboxylic acid (specifically Glu235) located at the bottom of the substrate-binding pocket was mutated. E235D and E235T variants were constructed and expressed in S. cerevisiae. The E235D variant showed higher preference for DMP than the parent type, while E235T showed improved affinity for ABTS. Additionally, the $\mathrm{pH}$ profiles of E235T for DMP, syringic acid and methyl syringate were altered, but not for the non-phenolic ABTS, suggesting that the oxidation of phenolic and non-phenolic compounds likely proceeds through distinct catalytic pathways. The same researchers also evaluated the role of the C-terminus on the MaL features (Andberg et al., 2009). Three different MaL mutants were constructed: the delDSGL559 mutant (a truncated C-terminal version of MaL), the L559G and the L559A variants. Overall changes in the $\mathrm{C}$-terminal plug addressed the significant role of this region in the MaL activity and stability. Indeed, the MaL crystal structure revealed that the L559A mutation certainly altered the overall geometry of the trinuclear $\mathrm{Cu}$ cluster.

The role of the C-terminus was also studied in the ERY4 laccase from Pleurotus eryngii to find out why the recombinant enzyme was not active in S. cerevisiae (Bleve et al., 2013). A total of six deletion variants (carrying Cterminal deletions of $2,5,8,11,14$ and 18 consecutive amino acids) and four site-specific mutants at the C-terminus (K532R, K532A, K532E and P530A) were designed, being all of them expressed in active form in yeast (except for the K532R mutant). It was concluded that this region may be 
important for the inactivation/activation mechanism of the enzyme since it lacks of proper processing in yeast.

The HRPL from $T$. versicolor expressed in $Y$. lypolytica was also rationally engineered to enhance the capacity to oxidize phenolic and nonphenolic substrates (Madzak et al., 2006), and bulky phenolic compounds (Galli et al., 2011). On the one hand, after replacing Asp206 (which strongly interacts with the phenolic substrate 2,5-xylidine) with Glu, Ala and Asn, the oxidation of several substrates was tested, revealing a 3-fold increase in the $k_{\text {cat }}$ towards ABTS for the most efficient D206N mutant when compared to the wild-type (Madzak et al., 2006). Interestingly, this substitution also led to a significant shift in the optimum $\mathrm{pH}$ value for DMP (a 1.4 unit increase). The same mutation was assayed during the laboratory evolution of the HRPL from basidiomycete PM1 for its activity in human blood, resulting in a comparable improvement (Mate et al., 2013b): a 2 unit increase in $\mathrm{pH}$ optimum over the parental type with DMP as substrate (see below). On the other hand, mutants were also generated in which four individual Phe residues at key positions at the entrance to the substrate binding pocket (specifically Phe162, Phe265, Phe332 and Phe337) were replaced by Ala (Galli et al., 2011). The F162A variant displayed higher oxidation efficiency towards the bulky phenols than the wild-type, and the F265A and F332A mutants consumed less substrate, possibly due to the absence of adequate hydrophobic interactions. The F337A variant was not active, which might be explained by the fact that this residue belongs to the second coordination sphere of $\mathrm{T} 1 \mathrm{Cu}$ and a change in this position gives rise to dramatic destabilization. As the F162A and F332A mutants showed enhanced oxidative capabilities towards bulky substrates, a double variant F162A/F332A was constructed behaving more efficient than the single mutant counterparts in transforming bisphenol A.

Very recently, the HRPL from the ascomycete Botrytis aclada has been rationally studied (Osipov et al., 2014). The non-conserved Leu499 residue in the axial position of the T1 site was substituted by Me and the crystal structures, the redox potential and the kinetic constants were determined. While the overall structures of the wild-type and the mutant were very similar, the mutation led to a decrease of $140 \mathrm{mV}$ in the $\mathrm{E}^{0}{ }_{\mathrm{T} 1}$ (+720 and $+580 \mathrm{mV}$ for the wild-type and the L499M variant, respectively) as well as to higher $K_{\mathrm{m}}$ values both for ABTS and DMP.

\subsection{Semi-rational approaches}

Most semi-rational approaches performed in laccases are experimentally supported by saturation mutagenesis, a reliable technique commonly employed to explore the characteristics of enzymes at hot-spot residues identified by rational analysis or directed evolution. With this method, a single codon can be replaced by all the codons that will generate the 20 naturally occurring amino acids, or a representative selection of those, depending on the degree of the degeneration chosen in the mutagenized codon (Lutz, 2010). This approach can be performed to 
simultaneously mutate several codons (i.e. combinatorial saturation mutagenesis - CSM), and sometimes performing iterative cycles so that optimal interactions and synergies between residues are revealed (Chica et al., 2005, Reetz and Carballeira, 2007).

i) Bacterial laccases: The CotA laccase from B. subtilis was recently subjected to saturation mutagenesis in order to assess the role of an acidic residue at the water exit channel (Asp116) in the mechanism of $\mathrm{O}_{2}$ reduction to water (Brissos et al., 2012; Silva et al., 2012) (Table 6). The five selected mutants (D116E, D116A, D116N, D116T and D116L) only showed small changes in the geometry of the copper centres. Nonetheless, turnover rates were drastically reduced and the optimal $\mathrm{pH}$ for the oxidation of substrates was downshifted around 1-2 units when compared with the native laccase. Furthermore, the crystal structures of the D116E, D116A and D116N variants were determined (Silva et al., 2012). Asp116 seems to be essential in the modulation of Glu498 protonation, -the latter being a structurally conserved residue placed at the dioxygen entrance channel. CSM was also employed to narrow the substrate specificity of the CotA laccase from B. subtillis (Gupta and Farinas, 2009; Gupta et al., 2010). The simultaneous randomization of 19 amino acids involved in the ABTS-bound, and the subsequent recombination of the best variants, gave rise to a double mutant (G417L-L386W) with strong preferences for ABTS over syringaldazine than the wild-type. Notably, this mutant also showed enhanced thermal stability (the half-life at $80^{\circ} \mathrm{C}$ was enhanced by $62 \mathrm{~min}$ ), despite the fact that the screening assay was designed for substrate specificity and not for thermostability.

ii) Fungal laccases: CSM was employed to increase turnover rates in the T2 mutant from Myceliopthora thermophila laccase (obtained by laboratory evolution for functional expression in S. cerevisiae; Bulter et al., 2003) focusing on the highly conserved ${ }_{509} \mathrm{VSG}_{511}$ tripeptide located in the neighbourhood of the $\mathrm{T} 1 \mathrm{Cu}$ site (Zumárraga et al., 2008a) (Table 6). Over 180,000 clones were screened, among which the S510G mutant showed about 3- and 8-fold higher catalytic efficiencies for ABTS and DMP, respectively. Moreover, the T1 site geometry of this laccase variant was altered but without having significant effects on the redox potential. The S510G mutation directly interacts with the C-terminal plug, which seems to modulate the entrance of $\mathrm{O}_{2}$ to the T2/T3 trinuclear cluster in ascomycete laccases (Andberg et al., 2009).

\subsection{Directed evolution and hybrid approaches}

Directed molecular evolution has become a powerful tool to develop biocatalysts with improved features or new functions (Cobb et al., 2012; Tracewell and Arnold, 2009). This approach recreates Darwinian principles of natural evolution (random mutation, gene recombination and selection), enabling the design of enzymes with properties of particular biotechnological interest in the absence of structural or mechanistic information (Arnold, 2009). In directed evolution the selection pressure is 
controlled by the researcher searching to improve a specific enzymatic trait, compressing the evolutionary time scale to just months or even days of work in the lab (Dalby, 2011; Esvelt et al., 2011). Of particular interest is the synergistic use of directed evolution and semi-rational approaches applied to laccases in order to improve or create enzymatic features, such as: functional heterologous expression and activity; performance in nonnatural environments like organic solvents, human blood or ionic liquids; and the design of chimeric laccases with combined properties (Tables $\mathbf{6}$ and 7).

\section{a) Directed evolution for functional expression and activity}

i) Bacterial laccases: The CotA laccase from Bacillus licheniformis was subjected to random and site-directed mutagenesis in order to improve its functional expression in E. coli (Koschorreck et al., 2009). After one round of error-prone PCR and 6,000 clones analysed, laccase variants containing the independent $\mathrm{K} 316 \mathrm{~N}$ and D500G mutations showed up to a 2 -fold increase in ABTS activity with respect to that of the wild-type. The double mutant K316N/D500G was then constructed to study the combinatorial effect of both mutations on laccase expression. This variant displayed 11.4fold higher expression level than the wild-type, also being more efficient in the conversion of ferulic acid and in the decolorization of industrial dyes. The metagenome-derived alkaline laccase Lac591 was evolved in E. coli with the aim of achieving better performing laccases for textile dye decolorization (Liu et al., 2011). After three rounds of error-prone PCR and screening, a mutant (the Lac3T93 variant) with 4.8 -fold increased specific activity toward DMP and higher decolorization efficiency for several dyes was obtained. The CotA laccase from $B$. subtilis was engineered using directed evolution and structure-based methods in order to increase the specificity for ABTS over syringaldazine (Gupta and Farinas, 2010). A library of CotA laccase genes was expressed in the bacterial spore coat and the corresponding laccase mutants were screened for ABTS specificity over syringaldazine. The best variant of this study (the CotA-ABTS-SD1 mutant) exhibited 120-fold higher specificity for ABTS than the wild-type.

ii) Fungal laccases: During the last 10 years, both medium- and highredox potential laccases have been heterologously expressed by means of laboratory evolution in yeast, mainly S. cerevisiae (Mate et al., 2011). There are four main reasons to use $S$. cerevisiae for the directed evolution of

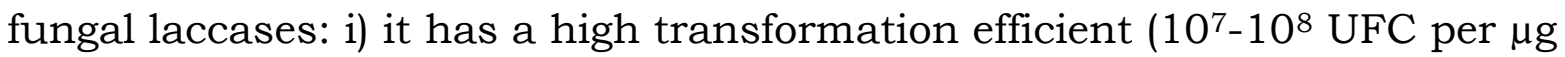
of DNA), comparable to that of E. coli (108-10 10 UFC per $\mu$ g of DNA); ii) it can secrete laccases to the extracellular medium, avoiding the cumbersome steps of cell lysis required in bacteria; iii) there are a wide variety of episomal uni- and bi-directional vectors available on the market that facilitates the recovery of improved variants; and iv) it shows a high frequency of homologous DNA recombination, which permits the in vivo shuffling of mutant libraries and the development of new tools for the creation of genetic diversity (Gonzalez-Perez et al., 2012, 2014). 
The first successful study about directed evolution of a fungal laccase was performed with the medium-redox potential laccase from the thermophilic ascomycete $M$. thermophila (MtL) (Bulter et al., 2003). The full laccase gene subjected to evolution comprised the mature sequence joined to the native prepro-leader sequence and the C-terminal tail, the latter two being cleaved from the mature protein during maturation. In total 20,000 clones were explored in 10 rounds of random mutagenesis combined with staggered extension process (StEP) and in vivo shuffling, giving rise to the highest expression levels of a laccase in $S$. cerevisiae reported so far (18 $\mathrm{mg} / \mathrm{L}$ ). The best mutant generated in this process (the T2 variant) accumulated 14 mutations that were responsible of a 170-fold improvement in the total activity, 8-fold in the expression levels and 22 -fold in the $k_{\text {cat }}$ for ABTS. It is worth noting that the most beneficial mutation $(\mathrm{H}(\mathrm{c} 2) \mathrm{R}, 10$-fold increase in total activity) introduced a Kex2 protease recognition site at the C-terminal tail, adjusting the laccase sequence to the different protease specificities of the heterologous host.

The success with MtL led to subsequent laboratory evolution for functional expression in $S$. cerevisiae of two HRPL: those from the ligninolytic basidiomycetes PM1 and Pycnoporus cinnabarinus (Maté et al., 2010; Camarero et al., 2012). PM1 laccase (PM1L) was subjected to eight rounds of directed evolution combined with semi-rational design (Maté et al., 2010) (Fig. 2A and 3A). The native signal sequence was replaced by the a-factor prepro-leader from $S$. cerevisiae (commonly used to express heterologous proteins in yeast; Zsebo et al., 1986), and the whole fusion gene was evolved to enhance the total laccase activity 34,000-fold over the parental type. Mutagenic libraries created with different DNA polymerases were recombined by in vivo DNA shuffling and/or in vivo assembly of mutant libraries with different mutational spectra (IvAM). After screening over 50,000 clones, 15 beneficial mutations were located at the signal prepro-leader (five mutations) and the mature protein (ten mutations), whilst the stability of the protein was preserved by a combined strategy that included: i) a high-throughput screening (HTS) for kinetic thermostability; ii) the recovery of beneficial mutations lost along the evolutionary process; and iii) the incorporation of beneficial mutations discovered in the parallel evolutionary study of the Pycnoporus cinnabarinus laccase (PcL) into the PM1L scaffold. The best performing mutant of this process (the OB-1 variant) had the highest levels of secretion ever reported for a HRPL in $S$. cerevisiae ( 8 $\mathrm{mg} / \mathrm{L})$, enhanced kinetics values for phenolic and nonphenolic substrates, as well as high stability in terms of $\mathrm{pH}$, organic cosolvent tolerance and temperature. Indeed, PM1L evolution was recently chosen as model to validate computational protocols (based on several FoldX algorithms and molecular dynamics simulations) which permit the quantification of the relative stability of mutants of HRPL (Christensen and Kepp, 2012). The protocols developed were applied to nine different PM1L mutants, in all cases showing good correlation with the experimental values. In a parallel directed evolution study, PcL was tailored using a similar strategy to that employed for PM1L (i.e., substitution of the native signal peptide by the a-factor prepro-leader and joint evolution of the a-PcL 
fusion gene (Camarero et al., 2012) (Fig. 2B). After six rounds of evolution coupled to a HTS assay based on the oxidation of natural and synthetic mediators, the total laccase activity was improved 8,000 times over the parent a-PcL. The final mutant of this study (the 3PO variant) accumulated a total of 15 mutations in the fusion gene. The five mutations located in the a-factor prepro-leader were responsible for a 40-fold enhancement in secretion by $S$. cerevisiae $(\sim 2 \mathrm{mg} / \mathrm{L})$, while the ten beneficial mutations in the mature protein led to a 13.7 -fold increase in the $k_{\text {cat }}$ for ABTS. Notably, the $\mathrm{pH}$ activity profile was shifted to more neutral $\mathrm{pH}$ values throughout this evolution, while thermostability was retained.

The POXA1b laccase from Pleurotus ostreatus was evolved with the aim of increasing its activity using $S$. cerevisiae as a host (Festa et al., 2008; Miele et al., 2010a). A library of 2,300 randomly mutated variants was screened by assaying activity towards ABTS (Festa et al., 2008) and DMP (Miele et al., 2010a), yielding laccase mutants with enhanced specific activity and/or improved stability. Moreover, molecular dynamics simulations of the wild-type enzyme and two mutants allowed the changes observed in laccase properties to be understood at the molecular level (Festa et al., 2008). Amongst the set of evolved variants, the most stable mutant and the one with the highest catalytic efficiency were selected as parental types to further improve laccase activity $v s$. ABTS (Miele et al., $2010 \mathrm{~b})$. The strategy involved the incorporation of the mutations of both parental genes into the same laccase gene scaffold, which was subsequently subjected to random mutagenesis and screening. The best performing POXA1b laccase mutant (the $1 \mathrm{H} 6 \mathrm{C}$ variant) had 5 -fold higher specific activity towards ABTS compared to the wild-type, as well as increased stability across the whole $\mathrm{pH}$ range (Miele et al., 2010b). Very recently, POXA1b wild-type and $1 \mathrm{H} 6$ mutant were produced in high levels in $A$. niger by attaching the signal peptide of $A$. niger glucoamylase to the mature laccase (Macellaro et al., 2014, Table 4).

Besides laboratory evolution in $S$. cerevisiae, there are few examples in the literature where fungal laccases have been engineered for heterologous expression in other yeast species. The $l c c 1$ gene coding for $T$. versicolor laccase was cloned into the genome of $Y$. lipolytica using either single or multiple integration sites (Theerachat et al., 2012). After checking for successful secretion into the culture media, the strain with a single integration was selected for expression and subsequent screening of mutant libraries. The best variant (the rM-4A mutant) contained two mutations (L185P/Q214K), which gave rise to a 5.8 -fold increase in the total activity compared to the wild-type, together with a 2.4 and 2.8-fold enhancement of the catalytic efficiency towards ABTS and DMP, respectively. Also, the laccase from the plant pathogen Fomes lignosus was functionally expressed in $P$. pastoris by constructing mutant libraries through ethyl methane sulfonate-based random mutagenesis (Hu et al., 2007). After screening 20,000 colonies, the best laccase variant (the PPM5 mutant) harboured four mutations that were responsible for a 3.7-fold enhancement in expression $(144 \mathrm{mg} / \mathrm{L})$, as well as a 1.4 -fold higher $k_{\text {cat }}$ for 
ABTS. Two of the mutations (specifically G160D and A167T) were found in the proximity of the water channel and they became hydrophilic amino acids, which might help water molecules to exit the trinuclear cluster, thereby explaining the increase of the $k_{\text {cat }}$.

\section{b) Directed evolution in non-natural environments}

One of the most attractive aspects of the combined use of directed evolution with rational and semi-rational strategies is the fact that it allows protein engineers to design new enzymes with functions not previously required in nature (Lutz and Bornscheuer, 2012). In particular, in recent years several evolution studies have been published on the improvement of laccase catalysis in non-natural media as diverse as organic solvents, alkaline media, human blood or ionic liquids (Table 6).

In terms of $\mathrm{MtL}$, the aforementioned $\mathrm{T} 2$ mutant was selected as template to improve activity and stability in the presence of organic cosolvents, a required feature to employ laccases in organic syntheses or bioremediation processes (Zumárraga et al., 2007). After validation of the HTS assay in $20 \%(\mathrm{v} / \mathrm{v})$ acetronitrile and $30 \%(\mathrm{v} / \mathrm{v})$ ethanol (Alcalde et al., 2005), five rounds of evolution were performed that led to the final variant, the R2 mutant. R2 accumulated six additional mutations (four in the mature protein and two in the C-terminal tail) and displayed a remarkable initial activity in the presence of high concentrations of co-solvents (e.g. in $50 \%$ ethanol (v/v), R2 kept around 20\% of the activity showed in aqueous solution). Interestingly, in the course of the 15 generations of evolution for functional expression in yeast and tolerance against organic co-solvents, the $\mathrm{pH}$ profile of MtL shifted progressively toward more alkaline $\mathrm{pH}$, clearly as a consequence of screening the mutant libraries at $\mathrm{pH}$ 5.0. This unexpected side-effect, combined with the fact that fungal laccases are highly attractive to use in processes where basic $\mathrm{pH}$ is a requisite (i.e. pulp biobleaching, organic syntheses or cofactor regeneration), made the R2 mutant a suitable departure point to tackle the evolution towards activity at basic $\mathrm{pH}$ (Torres-Salas et al., 2013). The R2 mutant was then subjected to five further cycles of error-prone PCR combined with different in vivo and in vitro DNA recombination methods, being the ratio of activity at $\mathrm{pH} 8$ to that at $\mathrm{pH} 5$ used as selection pressure factor. After screening over 12,000 clones, the final mutant (the IG-88 variant) harboured two beneficial mutations in the mature protein. IG- 88 exhibited $\mathrm{pH}$ activity profiles both for ABTS and DMP that were widely shifted towards an alkaline $\mathrm{pH}$ values (retaining $~ 90 \%$ of its activity at $\mathrm{pH} 4.0-6.0,50 \%$ at $\mathrm{pH} 7.0$, and even some activity detectable at $\mathrm{pH}$ 8.0). Additionally, it showed $k_{\text {cat }} / K_{\mathrm{m}}$ values significantly improved over the MtL-R2 parent at neutral $\mathrm{pH}$ (31- and 9-fold with ABTS and DMP, respectively), while at $\mathrm{pH} 4.0$ the improvement was slightly less pronounced (12- and 4-fold with ABTS and DMP, respectively). IG-88 variant accumulated two additional mutations with respect to the parental type, one of them being a highly conserved residue (Asp109) previously reported to be involved in keeping the overall geometry of the trinuclear site in M. albomyces laccase (Andberg et al., 2009). To sum up, a 
total of 20 generations of directed MtL evolution was performed in three different studies: heterologous expression in yeast (10 rounds, T2 mutant), stabilization in organic co-solvents ( 5 rounds, R2 mutant) and activity at alkaline $\mathrm{pH}$ (5 rounds, IG-88 mutant). The success of the in vitro evolution of MtL can be ascribed to the plasticity and robustness of this protein, able to accumulate 17 amino acid mutations in the mature laccase without compromising its overall stability.

In terms of HRPL, the secretion variant of the PM1L evolution $(\mathrm{OB}-1$ mutant) was recently used as the parental type to design a laccase that could function in human blood, so that it may be incorporated into 3Dnanobiodevices for biomedical purposes (Mate et al., 2013b) (Fig. 3A). Like all other HRPL, the OB-1 mutant was not active at neutral/alkaline pHs and it was strongly inhibited by modest concentration of halides, hampering its performance in human physiological fluids since human blood has a pH of 7.4 and it contains around $150 \mathrm{mM} \mathrm{NaCl}$. Accordingly, we established a HTS assay based on a surrogate blood (named blood buffer) that imitated the biochemical composition of human blood but that lacked coagulating factors and blood cells. OB-1 was subjected to four rounds of directed evolution combined with site-directed and saturation mutagenesis, the selection pressure being gradually increased from $\mathrm{pH} 6.5$ to physiological $\mathrm{pH}$ during the evolution. The final mutant obtained (the ChU-B variant) showed a 40,000-fold increase in total activity in blood buffer with respect to the parental type, as well as the highest tolerance to chloride yet reported for a basidiomycete HRPL, with an increase in the I50 for $\mathrm{Cl}^{-}$from $176 \mathrm{mM}$ to $1,025 \mathrm{mM}$ ( $\mathrm{I}_{50}$ was the concentration of $\mathrm{Cl}^{-}$at which the laccase keeps $50 \%$ of its activity). In addition, it displayed significant activity at neutral $\mathrm{pH}$ (retaining $\sim 50 \%$ and $\sim 20 \%$ of its activity for DMP and ABTS, respectively), while conserving a high-redox potential at the $\mathrm{T} 1 \mathrm{Cu}$. It was also tested on real human blood and plasma after over-expression in $P$. pastoris, revealing the mechanisms underlying this unprecedented improvement (Mate et al., 2013c). These unique features were a consequence of the accumulation of only two additional mutations in the mature protein (specifically F396I and F454E) (Fig. 3B), which led to activity in blood but at the expense of the thermal stability, a phenomenon similar to that observed throughout the evolutionary history of cytochrome $\mathrm{P}_{450}{ }_{\text {Вм} 3}$ from Bacillus megaterium (Fasan et al., 2008). Very recently, the ChU-B mutant was reported to be the first laccase able to catalyze the electro-oxidation of water to molecular oxygen by immobilization onto chemically modified electrodes (Pita et al., 2014). These results open promising perspectives for the sustainable production of hydrogen as a renewable source of energy. Furthermore, the blood tolerant laccase has been successfully incorporated into a self-powered biodevice with wireless signal transmission (Falk et al., 2014).

The latest example of directed evolution of HRPL towards tolerance in non-natural media is that of the laccase Lcc2 from T. versicolor, which was subjected to two rounds of random mutagenesis and screening towards improved ionic liquid resistance (Liu et al., 2013). The best variant from this study (the M3 mutant) displayed 4.5-fold stronger activity than the 
wild-type in the presence of $15 \%$ (v/v) of the ionic liquid [EMIM] [EtSO 4 ] (i.e. 1-ethyl-3-methylimidazolium ethyl sulfate). These findings show the potential of using HRPL as efficient catalysts for lignin degradation in homogeneous ionic solutions and consequently, for second-generation biofuel production.

\section{c) Chimeric laccases}

DNA recombination methods can be used to generate novel genes by combining DNA fragments sharing certain sequence identity, irrespective of their genetic background (Miyazaki and Arnold, 2004). In recent years, family shuffling has been proposed as an efficient strategy to construct chimeric laccases with improved features over the parental types (Table 7).

Two different laccases from the basidiomycete Lentinula edodes sharing less than 60\% homology in their cDNA sequences (Lcc1 and Lcc4) were recombined using the N-terminus of the lcc4 cDNA and the $\mathrm{C}$ terminus of the lccl cDNA (Nakagawa et al., 2010). The resulting chimeric laccase cDNA $(l c c 4 / 1)$ was expressed in tobacco BY-2 cells, giving rise to the Lcc4/1 laccase. As expected, Lcc4/1 was a chimera of the two parental laccases, being produced at similar levels as Lcc1, with $K_{\mathrm{m}}$ values for phenolic and non-phenolic substrates similar to those of Lcc4, and with an intermediate $\mathrm{pH}$ and temperature profile between the two parental types.

Despite the good results obtained in the creation of the L. edodes chimeric laccase, the expression system based on tobacco cell culture cannot be used to screen a large number of recombinant proteins, dramatically reducing the chances of obtaining chimeric enzymes that perform better than the parental types. This drawback can be overcome by taking advantage of the homologous recombination in $S$. cerevisiae (Gonzalez-Perez et al., 2012). Laccase chimeras of the Trametes sp. strain C30 were constructed by yeast-mediated homologous recombination of four cDNAs (lac1, lac2, lac3 and lac5), which shared 65-71\% DNA sequence identity (Cusano et al., 2009). The best chimeras (LAC131, LAC232 and LAC 535) apparently exhibited similar kinetic parameters at acidic $\mathrm{pH}$ to those obtained for the LAC3 reference laccase (a low-redox potential laccase previously expressed in yeast; Klonowska et al., 2005). However, LAC131 and LAC232 chimeras were more tolerant to alkaline $\mathrm{pH}$, showing 5- and 12 -fold higher catalytic efficiencies, respectively, than LAC3 at pH 8.0, as well as $\mathrm{pH}$ activity profiles shifted toward basic $\mathrm{pH}$ values.

DNA shuffling in S. cerevisiae has also been employed to generate chimeric HRPL by directed evolution (Pardo et al., 2012). The cDNA of the final variants of the evolution for expression in yeast of PM1L and PcL (OB1 and $3 \mathrm{PO}$ mutants, respectively: 51\% DNA sequence identity) were recombined in vitro and in vivo by CLERY (combinatorial libraries enhanced by recombination in yeast; Abécassis et al., 2000). Laccase hybrids with up to six crossover events per sequence were identified, which generated active chimeric laccases with combined features in terms of $\mathrm{pH}$ activity, substrate 
affinity and thermal stability. Unexpectedly, several laccase chimeras exhibited stronger thermal stabilities than both parent types. This effect may be attributed to the accumulation of neutral mutations known to be beneficial for the stabilization of the protein structure (Bloom et al., 2006).

Very recently, the ERY4 laccase from $P$. eryngii has been modified with the $\mathrm{N}-, \mathrm{C}$ - and both $\mathrm{N}$ - and C-terminal regions of ERY3 laccase, another laccase isoform of $P$. eryngii, to get the enzyme expressed in active form in S. cerevisiae (Bleve et al., 2014). Among the set of chimeric laccases, the best performing enzyme in terms of activity and stability was the result of substituting both the $\mathrm{N}$ - and the C-terminal regions. Significantly, this chimera was successfully displayed on the cell wall of $S$. cerevisiae by attaching either the Pir2 or the Flo1 anchor proteins to the Nterminal of the laccase.

\section{CONCLUSIONS AND OUTLOOK}

Over the years, laccases have become very attractive candidates for protein engineering as a consequence of their broad oxidative capabilities and consequently, their strong potential application in different industrial sectors. Incorporating targeted mutations into the laccase scaffold has permitted researches to inquire into the influence of 'hot spot' amino acid residues on several laccase features, such as the redox potential, catalytic efficiency or thermal stability. The creation of 'smart libraries' coupled to ad-hoc HTS assays has helped to surpass the difficulties encountered when using strict rational design. Thus, directed evolution combined with hybrid strategies have proven to be successful in achieving functional heterologous expression and activity, adaptation to non-natural environments and for the design of laccase chimeras with combined traits. In most of these experiments, homologous recombination in S. cerevisiae has permitted detrimental mutations to be sorted out, whilst accelerating the full in vitro evolution approach.

Among the remaining challenges in laccase engineering are the increasing of the redox potential at the $\mathrm{T} 1 \mathrm{Cu}$ site beyond the nature limits (above $+800 \mathrm{mV}$ ) without sacrificing neither the stability nor the catalysis (Abdellaoui et al., 2013) and the design of ad-hoc high efficient laccases acting on redox mediators while surpassing the inhibitory constraints (Sayut et al., 2010). Even though these milestones could be achieved, laccase large-scale production (at the scale of g/L) is the key to access to the industry with competitive costs. Therefore, suitable heterologous expression systems with tolerance to high laccase expression levels (i.e. with low metabolic drains and/or high resistance to laccase toxicity) must be first accomplished.

In the forthcoming years, it is expected that the combination of laboratory evolution with both rational and semi-rational strategies, including molecular dynamics and quantum mechanics/molecular mechanics simulations, will lead to the development of laccases with exciting biotechnological properties and produced at high titers whilst enhancing 
our understanding, at the molecular level, of the mechanisms that govern the behaviour of this thrilling group of oxidoreductases.

\section{ACKNOWLEDGEMENTS}

The laboratory of MA gratefully acknowledges the financial support received from the EU (FP7-KBBE-2013-7-613549-INDOX, FP7-People2013-ITN-607793 and COST-Action CM1303 Systems Biocatalysis) and the Spanish Government (BIO2010-19697-EVOFACEL, BIO2013-43407-RDEWRY and CAMBIOS-RTC-2014-1777-3) projects.

\section{DECLARATION OF INTEREST}

The authors have no conflict of interests to declare.

\section{REFERENCES}

Abdellaoui S, Noiriel A, Henkens R, Bonaventura C, Blum LJ, Doumeche B. A 96-well electrochemical method for the screening of enzymatic activities. Anal Chem 2013;85:3690-7.

Abécassis V, Pompon D, Truan G. High efficiency family shuffling based on multi-step PCR and in vivo DNA recombination in yeast: statistical and functional analysis of a combinatorial library between human cytochrome P450 1A1 and 1A2. Nucleic Acids Res 2000;28:1-10.

Abyanova AR, Chulkin AM, Vavilova EA, Fedorova TV, Loginov DS, Koroleva $\mathrm{OV}$ et al. A heterologous production of the Trametes hirsuta laccase in the fungus Penicillium canescens. Appl Biochem Microb 2010;46:313-7.

Alcalde M. Laccases: biological functions, molecular structure and industrial applications. In: Polaina J, MacCabe AP, editors. Industrial enzymes. Structure, function and applications. Dordrecht: Springer; 2007. p. 461-76.

Alcalde M, Bulter T, Zumarraga M, Garcia-Arellano H, Mencia M, Plou FJ et al. Screening mutant libraries of fungal laccases in the presence of organic solvents. J Biomol Screen 2005;10:624-31.

Alves AMCR, Record E, Lomascolo A, Scholtmeijer K, Asther M, Wessels JGH et al. Highly efficient production of laccase by the basidiomycete Pycnoporus cinnabarinus. Appl Environ Microbiol 2004;70: 6379-6384.

Andberg M, Hakulinen N, Auer S, Saloheimo M, Koivula A, Rouvinen J et al. Essential role of the C-terminus in Melanocarpus albomyces laccase for enzyme production, catalytic properties and structure. FEBS J 2009;276:6285-300. 
Arnold FH. How proteins adapt: lessons from directed evolution. Cold Spring Harb Sym 2009;74:41-6.

Bailey MR, Woodard SL, Callaway E, Beifuss K, Magallanes-Lundback M et al. Improved recovery of active recombinant laccase from maize seed. Appl Microbiol Biot 2004;63:390-7.

Baker CJO, White TC. Expression of laccase I and IV genes from Trametes versicolor in Trichoderma reesei. In: Argyropoulos DS, editor. Oxidative delignification chemistry. Fundamental and catalysis. American Chemical Society; 2001. p. 413-26.

Baldrian P. Fungal laccases-occurrence and properties. FEMS Microbiol Rev 2006;30:215-42.

Beloqui A, Pita M, Polaina J, Martinez-Arias A, Golyshina OV, Zumarraga M et al. Novel polyphenol oxidase mined from a metagenome expression library of bovine rumen - Biochemical properties, structural analysis, and phylogenetic relationships. J Biol Chem 2006;281:22933-942.

Benghazi L, Record E, Suárez A, Gomez-Vidal J, Martínez J, Rubia T. Production of the Phanerochaete flavido-alba laccase in Aspergillus niger for synthetic dyes decolorization and biotransformation. World J Microbiol Biotechnol 2013;1-11.

Berka RM, Schneider P, Golightly EJ, Brown SH, Madden M, Brown KM et al. Characterization of the gene encoding an extracellular laccase of Myceliophthora thermophila and analysis of the recombinant enzyme expressed in Aspergillus oryzae. Appl Environ Microbiol 1997;63:3151-7.

Bleve, G., Lezzi, C., Mita, G., Rampino, P., Perrotta, C., Villanova, L et al. Molecular cloning and heterologous expression of a laccase gene from Pleurotus eryngii in free and immobilized Saccharomyces cerevisiae cells. Appl Microbiol Biot 2008;79:731-41.

Bleve G, Lezzi C, Spagnolo S, Tasco G, Tufariello M, Casadio R et al. 2013. Role of the C-terminus of Pleurotus eryngii Ery4 laccase in determining enzyme structure, catalytic properties and stability. Protein Eng Des Sel 2013;26:1-13.

Bleve G, Lezzi C, Spagnolo S, Rampino P, Perrotta C, Mita G et al. Construction of a laccase chimerical gene: Recombinant protein characterization and gene expression via yeast surface display. Appl Biochem Biotechnol 2014;172:2916-31.

Bloom JD, Labthavikul ST, Otey CR, Arnold FH. Protein stability promotes evolvability. P Natl Acad Sci USA 2006;103:5869-74. 
Bohlin C, Jonsson LJ, Roth R, van Zyl WH. Heterologous expression of Trametes versicolor laccase in Pichia pastoris and Aspergillus niger. Appl Biochem Biotech 2006;129:195-214.

Bonomo RP, Boudet AM, Cozzolino R, Rizzarelli E, Santoro AM, Sterjiades R et al. 1998. A comparative study of two isoforms of laccase secreted by the white-rot fungus Rigidoporus lignosus, exhibiting significant structural and functional differences. J Inorg Biochem 1998;71:205-11.

Brander S, Mikkelsen JD, Kepp KP. 2014. Characterization of an alkaliand halide-resistant laccase expressed in E. coli: CotA from Bacillus clausii. PLoS ONE 9:e99402.

Brijwani K, Rigdon A, Vadlani PV. Fungal laccases: production, function, and applications in food processing. Enzyme Res 2010; Article ID 149748.

Brissos V, Chen Z, Martins LO. The kinetic role of carboxylate residues in the proximity of the trinuclear centre in the $\mathrm{O}_{2}$ reactivity of CotA-laccase. Dalton Trans 2012;41:6247-55.

Bulter T, Alcalde M, Sieber V, Meinhold P, Schlachtbauer C, Arnold FH. Functional expression of a fungal laccase in Saccharomyces cerevisiae by directed evolution. Appl Environ Microbiol 2003;69:987-95.

Call HP, Mucke I. History, overview and applications of mediated ligninolytic systems, especially laccase-mediator-systems (Lignozym ${ }^{\circledR}$ process). J Biotechnol 1997;53:163-202.

Camarero S, Pardo I, Cañas AI, Molina P, Record E, Martinez AT et al. Engineering platforms for directed evolution of laccase from Pycnoporus cinnabarinus. Appl Environ Microbiol 2012;78:1370-84.

Cañas AI, Camarero S. Laccases and their natural mediators: Biotechnological tools for sustainable eco-friendly processes. Biotechnol Adv 2010;28:694-705.

Chica RA, Doucet N, Pelletier JN. Semi-rational approaches to engineering enzyme activity: combining the benefits of directed evolution and rational design. Curr Op Biotech 2005;16:378-84.

Christensen NJ, Kepp KP. Accurate stabilities of laccase mutants predicted with a modified FoldX protocol. J Chem Inf Model 2012;52:3028-42.

Cobb RE, Si T, Zhao H. Directed evolution: an evolving and enabling synthetic biology tool. Curr Opin Chem Biol 2012;16:285-91.

Colao MC, Lupino S, Garzillo AM, Buonocore V, Ruzzi M. Heterologous expression of lcc 1 gene from Trametes trogii in Pichia pastoris and 
characterization of the recombinant enzyme. Microb Cell Fact 2006;5: 3142.

Collins PJ, Dobson ADW. Regulation of laccase gene transcription in Trametes versicolor. Appl Environ Microbiol 1997;63:3444-50.

Couto SR, Herrera JLT. Industrial and biotechnological applications of laccases: A review. Biotechnol Adv 2006;24:500-13.

Cui TJ, Wang XT, Zhou HM, Hong YZ, Xiao YZ, Cui TJ et al. High output of a Trametes laccase in Pichia pastoris and characterization of recombinant enzymes. Chinese J Biotechnol 2007;23:1055-9.

Cusano AM, Mekmouche Y, Meglecz E, Tron T. Plasticity of laccase generated by homeologous recombination in yeast. FEBS J 2009;276: 5471-80.

Dalby PA. Strategy and success for the directed evolution of enzymes. Curr Opin Struc Biol 2011;21:473-80.

Davies GJ, Ducros V. Laccase. In: Messerschmidt A, Huber R, Wieghardt K, Poulos T., editors. Handbook of metalloproteins. Hoboken: Wiley; 2006. p. 1359-68.

de Wilde C, Uzan E, Zhou ZY, Kruus K, Andberg M, Buchert J et al. (2008) Transgenic rice as a novel production system for Melanocarpus and Pycnoporus laccases. Transgenic Res 2008;17:515-27.

Dubé E, Shareck F, Hurtubise Y, Daneault C, Beauregard M. 2008. Homologous cloning, expression, and characterisation of a laccase from Streptomyces coelicolor and enzymatic decolourisation of an indigo dye. Appl Microbiol Biotechnol 2008;79:597-603.

Durão P, Bento I, Fernandes AT, Melo EP, Lindley PF, Martins LO. Perturbations of the T1 copper site in the CotA laccase from Bacillus subtilis: structural, biochemical, enzymatic and stability studies. J Biol Inorg Chem 2006; 11:514-26.

Durão P, Chen Z, Silva CS, Soares CM, Pereira MM, Todorovic S et al. Proximal mutations at the type 1 copper site of CotA laccase: spectroscopic, redox, kinetic and structural characterization of I494A and L386A mutants. Biochem J 2008;412:339-46.

Endo K, Hayashi Y, Hibi T, Hosono K, Beppu T, Ueda K. Enzymological characterization of EpoA, a laccase-like phenol oxidase produced by Streptomyces griseus. J Biochem 2003;133:671-7.

Esvelt KM, Carlson JC, Liu DR. A system for the continuous directed evolution of biomolecules. 2011; Nature 472:499-503. 
Falk M, Alcalde M, Bartlett P, De Lacey AL, Gorton L, Gutierrez-Sanchez C, et al. Self-powered wireless carbohydrate/oxygen sensitive biodevice based on radio signal transmission. PLoS One 2014;9:e109104.

Fang Z, Li T, Wang Q, Zhang X, Peng H, Fang W et al. A bacterial laccase from marine microbial metagenome exhibiting chloride tolerance and dye decolorization ability. Appl Microbiol Biotechnol 2011;89:1103-10.

Fasan R, Meharenna YT, Snow CD, Poulos TL, Arnold FH. Evolutionary history of a specialized P450 propane monooxygenase. J Mol Biol 2008;383:1069-80.

Fernandes AT, Soares CM, Pereira MM, Huber R, Grass G, Martins LO. A robust metallo-oxidase from the hyperthermophilic bacterium Aquifex aeolicus. FEBS J 2007;274:2683-94.

Fernandes AT, Damas JM, Todorovic S, Huber R, Baratto MC, Pogni R et al. The multicopper oxidase from the archaeon Pyrobaculum aerophilum shows nitrous oxide reductase activity. FEBS J 2010;277:3176-89.

Festa G, Autore F, Fraternali F, Giardina P, Sannia G. Development of new laccases by directed evolution: Functional and computational analyses. Proteins 2008;72:25-34.

Gallaway J, Wheeldon I, Rincon R, Atanassov P, Banta S, Barton SC. Oxygen-reducing enzyme cathodes produced from SLAC, a small laccase from Streptomyces coelicolor. Biosens Bioelectron 2008;23:1229-35.

Galli C, Gentili P, Jolivalt C, Madzak C, Vadala R. How is the reactivity of laccase affected by single-point mutations? Engineering laccase for improved activity towards sterically demanding substrates. App Microbiol Biot 2011;91:123-31.

García-Ruiz E, Maté D, Ballesteros A, Martinez AT, Alcalde M. Evolving thermostability in mutant libraries of ligninolytic oxidoreductases expressed in yeast. Microb Cell Fact 2010;9:17.

Garcia-Ruiz E, Mate DM, Gonzalez-Perez D, Molina-Espeja P, Camarero S, Martinez AT et al. Directed evolution of ligninolytic oxidoreductases: from functional expression to stabilization and beyond. In: Riva S. Fessner WD, editors. Cascade Biocatalysis. Hoboken: Wiley; 2014. p. 1-22.

Garg SN, Baranwal R, Chhabra M, Mishra S, Chaudhuri TK, Bisaria VS. Laccase of Cyathus bulleri: structural, catalytic characterization and expression in Escherichia coli. Biochim Biophys Acta 2008;1784:259-68.

Garzillo AM, Colao MC, Buonocore V, Oliva R, Falcigno L, Saviano M et al. Structural and kinetic characterization of native laccases from Pleurotus 
ostreatus, Rigidoporus lignosus, and Trametes trogii. J Protein Chem 2001;20:191-201.

Georgescu R, Bandara G, Sun L. Saturation mutagenesis. In: Arnold FH, Georgiou G. Directed evolution library creation. Methods in molecular biology. Totowa: Humana Press; 2003. p. 75-83.

Gianfreda L, Xu F, Bollag J. Laccases: a useful group of oxidoreductive enzymes. Bioremediat J 1999;3:1-25.

Giardina P, Faraco V, Pezzella C, Piscitelli A, Vanhulle S, Sannia G. Laccases: a never-ending story. Cell Mol Life Sci 2010;67:369-85.

Gonzalez-Perez D, Garcia-Ruiz, E, Alcalde M. Saccharomyces cerevisiae in directed evolution: An efficient tool to improve enzymes. Bioengineered 2012;3:172-7.

Gonzalez-Perez D, Molina-Espeja, P., Garcia-Ruiz, E, Alcalde M. Mutagenic organized recombination process by homologous in vivo grouping (MORPHING) for directed enzyme evolution. PLoS One 2014;9:e90919.

Greimel KJ, Perz V, Koren K, Feola R, Temel A, Sohar C et al. Banning toxic heavy-metal catalysts from paints: enzymatic cross-linking of alkyd resins. Green Chem 2013;15:381-8.

Gunne M, Höppner A, Hagedoorn PL, Urlacher VB. 2014. Structural and redox properties of the small laccase Ssl1 from Streptomyces sviceus. FEBS J 281:4307-18.

Gupta N, Farinas ET. Narrowing laccase substrate specificity using active site saturation mutagenesis. Comb Chem High T Scr 2009;12:269-74.

Gupta N, Lee FS, Farinas ET. Laboratory evolution of laccase for substrate specificity. J Mol Catal B-Enzym 2010;62:230-4.

Gupta N, Farinas ET. Directed evolution of CotA laccase for increased substrate specificity using Bacillus subtilis spores. Protein Eng Des Sel 2010;23:679-82.

Gupta A, Nederlof I, Sottini S, Tepper AWJW, Groenen EJJ, Thomassen EAJ et al. Involvement of Tyr108 in the enzyme mechanism of the small laccase from Streptomyces coelicolor. J Am Chem Soc 2012;134:18213-6.

Hirai H, Kashima Y, Hayashi K, Sugiura T, Yamagishi K, Kawagishi H et al. Efficient expression of laccase gene from white-rot fungus Schizophyllum commune in a transgenic tobacco plant. FEMS Microbiol Lett 2008;286:130-5. 
Hong F, Meinander NQ, Jonsson LJ. Fermentation strategies for improved heterologous expression of laccase in Pichia pastoris. Biotechnol Bioeng 2002;79:438-49.

Hoshida H, Nakao M, Kanazawa H, Kubo K, Hakukawa T, Morimasa K et al. Isolation of five laccase gene sequences from the white-rot fungus Trametes sanguinea by PCR, and cloning, characterization and expression of the laccase cDNA in yeasts. J Biosci Bioeng 2001;92:372-80.

Hoshida H, Fujita T, Murata K, Kubo K, Akada R. Copper-dependent production of a Pycnoporus coccineus extracellular laccase in Aspergillus oryzae and Saccharomyces cerevisiae. Biosci Biotech Bioch 2005;69:10907.

Hu MR, Chao YP, Zhang GQ, Yang XQ, Xue ZQ, Qian SJ. Molecular evolution of Fome lignosus laccase by ethyl methane sulfonate-based random mutagenesis in vitro. Biomol Eng 2007;24:619-24.

Jung HC, Xu F, Li KC. Purification and characterization of laccase from wood-degrading fungus Trichophyton rubrum LKY-7. Enzyme Microb Technol 2002;30:161-8.

Kallio JP, Auer S, Jänis J, Andberg M, Kruus K, Rouvinen $\mathrm{J}$ et al. Structure-function studies of a Melanocarpus albomyces laccase suggest a pathway for oxidation of phenolic compounds. J Mol Biol 2009;392:895909.

Kataoka K, Kogi H, Tsujimura S, Sakurai T. Modifications of laccase activities of copper efflux oxidase, $\mathrm{CueO}$ by synergistic mutations in the first and second coordination spheres of the type I copper center. Biochem Bioph Res Co 2013;431:393-7.

Kiiskinen LL, Kruus K, Bailey M, Ylosmaki E, Siika-aho M, Saloheimo M. Expression of Melanocarpus albomyces laccase in Trichoderma reesei and characterization of the purified enzyme. Microbiology 2004;150:3065-74.

Kittl R, Gonaus C, Pillei C, Haltrich D, Ludwig R. Constitutive expression of Botrytis aclada laccase in Pichia pastoris. Bioengineered 2012a;3:172-7.

Kittl R, Mueangtoom K, Gonaus C, Khazaneh ST, Sygmund C, Haltrich D et al. A chloride tolerant laccase from the plant pathogen ascomycete Botrytis aclada expressed at high levels in Pichia pastoris. J Biotechnol 2012b;157:304-14.

Klonowska A, Gaudin C, Fournel A, Asso M, Le Petit J, Giorgi M et al. Characterization of a low redox potential laccase from the basidiomycete C30. Eur J Biochem 2002;269:6119-25. 
Klonowska A, Gaudin C, Asso M, Fournel A, Reglier M, Tron T. LAC3, a new low redox potential laccase from Trametes sp. strain C30 obtained as a recombinant protein in yeast. Enzyme Microb Tech 2005;36:34-41.

Kojima Y, Tsukuda Y, Kawai Y, Tsukamoto A, Sugiura J, Sakaino M et al. Cloning, sequence-analysis, and expression of ligninolytic phenoloxidase genes of the white-rot basidiomycete Coriolus hirsutus. J Biol Chem 1990;265:15224-30.

Koschorreck K, Schmid R, Urlacher V. Improving the functional expression of a Bacillus licheniformis laccase by random and site-directed mutagenesis. BMC Biotechnol 2009;9:12.

Kudanga T, Le Roes-Hill M. Laccase applications in biofuels production: current status and future prospects. Appl Microbiol Biotechnol 2014;98:6525-42.

Kurose S, Kataoka K, Shinohara N, Miura Y, Tsutsumi M, Tsujimura S et al. Modification of spectroscopic properties and catalytic activity of Escherichia coli CueO by mutations of methionine 510, the axial ligand to the type I Cu. B Chem Soc Jpn 2009;82:504-8.

Kunamneni A, Plou FJ, Ballesteros, A, Alcalde M. Laccases and their applications: a patent review. Recent Pat Biotechnol 2008a;2:10-24.

Kunamneni A, Camarero S, García C, Plou FJ, Ballesteros A, Alcalde M. Engineering and applications of fungal laccases for organic synthesis. Microb Cell Fact 2008b;7:32.

Lang M, Kanost MR, Gorman MJ. Multicopper oxidase-3 is a laccase associated with the peritrophic matrix of Anopheles gambiae. PLoS One 2012;7:e33985.

Larrondo LF, Avila M, Salas L, Cullen D, Vicuña R. Heterologous expression of laccase cDNA from Ceriporiopsis subvermispora yields copper-activated apoprotein and complex isoform patterns. Microbiology 2003;149:1177-82.

Laufer Z, Beckett RP, Minibayeva FV, Luthje S, Bottger M. Diversity of laccases from lichens in suborder Peltigerineae. Bryologist 2009;112: 41826.

Lee IY, Jung $\mathrm{KH}$, Lee $\mathrm{CH}$, Park YH. Enhanced production of laccase in Trametes vesicolor by the addition of ethanol. Biotechnol Lett 1999;21:9658.

Li KC, Xu F, Eriksson KEL. Comparison of fungal laccases and redox mediators in oxidation of a nonphenolic lignin model compound. Appl Environ Microbiol 1999;65:2654-60. 
$\mathrm{Li} \mathrm{H}$, Webb SP, Ivanic J, Jensen JH Determinants of the relative reduction potentials of type- 1 copper sites in proteins. J Am Chem Soc 2004;126: 8010-9.

Li J, Hong Y, Xiao Y, Xu Y, Fang W. High production of laccase B from Trametes sp. in Pichia pastoris. World J Microb Biot 2007;23:741-5.

Liu W, Chao Y, Liu S, Bao H, Qian S. Molecular cloning and characterization of a laccase gene from the basidiomycete Fome lignosus and expression in Pichia pastoris. Appl Microb Biot 2003;63:174-81.

Liu YH, Ye M, Lu Y, Zhang X, Li G. Improving the decolorization for textile dyes of a metagenome-derived alkaline laccase by directed evolution. Appl Microbiol Biotechnol 2011;91:667-75.

Liu H, Zhu L, Bocola M, Chen N, Spiess AC, Schwaneberg U. Directed laccase evolution for improved ionic liquid resistance. Green Chem 2013;15:1348-55.

Luna-Acosta A, Rosenfeld E, Amari M, Fruitier-Arnaudin I, Bustamante P, Thomas-Guyon H. First evidence of laccase activity in the Pacific oyster Crassostrea gigas. Fish Shellfish Immunol 2010;28:719-26.

Lutz S. Beyond directed evolution - Semi-rational protein engineering and design. Curr Op Biotech 2010;21:734-43.

Lutz S, Borscheuer UT. Protein engineering handbook, Volume 3. Hoboken: Wiley; 2012.

Macellaro G, Baratto M, Piscitelli A, Pezzella C, Fabrizi de Biani F, Palmese A et al. Effective mutations in a high redox potential laccase from Pleurotus ostreatus. Appl Microbiol Biotechnol 2014;98:4949-61.

Machczynski MC, Vijgenboom E, Samyn B, Canters GW. Characterization of SLAC: A small laccase from Streptomyces coelicolor with unprecedented activity. Protein Sci 2004;13:2388-97.

Madzak C, Otterbein L, Chamkha M, Moukha S, Asther M, Gaillardin C et al. Heterologous production of a laccase from the basidiomycete Pycnoporus cinnabarinus in the dimorphic yeast Yarrowia lipolytica. FEMS Yeast Res 2005;5:635-46.

Madzak C, Mimmi MC, Caminade E, Brault A, Baumberger S, Briozzo P et al. Shifting the optimal $\mathrm{pH}$ of activity for a laccase from the fungus Trametes versicolor by structure-based mutagenesis. Protein Eng Des Sel 2006;19:77-84.

Martins LO, Soares CM, Pereira MM, Teixeira M, Costa T, Jones GH et al. Molecular and biochemical characterization of a highly stable bacterial 
laccase that occurs as a structural component of the Bacillus subtilis endospore coat. J Biol Chem 2002;277:18849-59.

Maté D, García-Burgos C, García-Ruiz E, Ballesteros AO, Camarero S, Alcalde M. Laboratory evolution of high-redox potential laccases. Chem Biol 2010;17:1030-41.

Maté D, García-Ruiz E, Camarero S, Alcalde M. Directed evolution of fungal laccases. Curr Genomics 2011;12:113-22.

Mate DM, Garcia-Ruiz E, Camarero S, Shubin VV, Falk M, Shleev S et al. Switching from blue to yellow: Altering the spectral properties of a high redox potential laccase by directed evolution. Biocatal Biotransfor 2013a;31:8-21.

Mate DM, Gonzalez-Perez D, Falk M, Kittl R, Pita M, De Lacey AL et al. Blood tolerant laccases by directed evolution. Chem Biol 2013b;20:223-31.

Mate DM, Gonzalez-Perez D, Kittl R, Ludwig R, Alcalde M. Functional expression of a blood tolerant laccase in Pichia pastoris. BMC Biotechnol 2013c;13:38.

Mayer AM, Staples RC. Laccase: new functions for an old enzyme. Phytochemistry 2002;60:551-65.

Mekmouche Y, Zhou S, Cusano AM, Record E, Lomascolo A, Robert V et al. 2014. Gram-scale production of a basidiomycetous laccase in Aspergillus niger. J. Biosci Bioeng 2014;117:25-7.

Melo EP, Fernandes AT, Durao P, Martins LO. Insight into stability of CotA laccase from the spore coat of Bacillus subtilis. Biochem Soc Trans 2007;35:1579-82.

Miele A, Giardina P, Sannia G, Faraco V. Random mutants of a Pleurotus ostreatus laccase as new biocatalysts for industrial effluents bioremediation. J Appl Microbiol 2010a;108:998-1006.

Miele A, Giardina P, Notomista E, Piscitelli A, Sannia G, Faraco V. A semirational approach to engineering laccase enzymes. Mol Biotechnol 2010b;46:149-56.

Miessner M, Crescenzi O, Napolitano A, Prota G, Andersen SO, Peter, MG. Biphenyltetrols and dibenzofuranones from oxidative coupling of resorcinols with 4-alkylpyrocatechols: New clues to the mechanism of insect cuticle sclerotization. Helv Chim Acta 1991;74:1205-212.

Miura Y, Tsujimura S, Kurose S, Kamitaka Y, Kataoka K, Sakurai T et al. Direct electrochemistry of CueO and its mutants at residues to and near type I Cu for oxygen-reducing biocathode. Fuel Cells 2009;9:70-8. 
Miyazaki K, Arnold FH. In vitro DNA recombination. In: Clackson $\mathrm{T}$, Lowman $\mathrm{H}$, editors. Phage display: A practical approach. New York: Oxford University Press; 2004. p. 43-60.

Mogharabi M, Faramarzi MA. Laccase and laccase-mediated systems in the synthesis of organic compounds. Adv Synth Catal 2014;356:897-927.

Mohammadian M, Fathi-Roudsari M, Mollania N, Badoei-Dalfard A, Khajeh K. Enhanced expression of a recombinant bacterial laccase at low temperature and microaerobic conditions: purification and biochemical characterization. J Ind Microbiol Biotechnol 2010;37:863-9.

Molina-Guijarro JM, Pérez J, Muñoz-Dorado J, Guillén F, Moya R, Hernández $\mathrm{M}$ et al. Detoxification of azo dyes by a novel $\mathrm{pH}$-versatile, saltresistant laccase from Streptomyces ipomoea. Int Microbiol 2009;12:13-21.

Mollania N, Khajeh K, Ranjbar B, Hosseinkhani S. Enhancement of a bacterial laccase thermostability through directed mutagenesis of a surface loop. Enzyme Microb Technol 2011;49:446-52.

Morozova OV, Shumakovich GP, Gorbacheva MA, Shleev SV, Yaropolov AI. "Blue" laccases. Biochemistry-Moscow 2007a;72:1136-50.

Morozova OV, Shumakovich GP, Shleev SV, Yaropolov YI. Laccase-mediator systems and their applications: A review. Appl Biochem Microb 2007b;43:523-35.

Mot A.C, Silaghi-Dumitrescu R. Laccases: complex architectures for oneelectron oxidations. Biochemistry-Moscow. 2012;77:1395-1407.

Nakagawa Y, Sakamoto Y, Kikuchi S, Sato T, Yano A. A chimeric laccase with hybrid properties of the parental Lentinula edodes laccases. Microbiol Res 2010;165:392-401.

Otterbein L, Record E, Longhi S, Asther M, Moukha S. (2000) Molecular cloning of the cDNA encoding laccase from Pycnoporus cinnabarinus I-937 and expression in Pichia pastoris. Eur J Biochem 2000;267:1619-25.

Osipov E, Polyakov K, Kittl R, Shleev S, Dorovatovsky P, Tikhonova T et al. Effect of the L499M mutation of the ascomycetous Botrytis aclada laccase on redox potential and catalytic properties. Acta Crystallogr D 2014:70:2913-23.

Osma JF, Toca-Herrera JL, Rodriguez-Couto S. Uses of laccases in the food industry. Enzyme Res 2010; Article ID 918761.

Palmer AE, Szilagyi RK, Cherry JR, Jones A, Xu F, Solomon EI. Spectroscopic characterization of the Leu513His variant of fungal laccase: 
Effect of increased axial ligand interaction on the geometric and electronic structure of the type $1 \mathrm{Cu}$ site. Inorg Chem 2003;42:4006-17.

Pardo I, Vicente AI, Mate DM, Alcalde M, Camarero S. Development of chimeric laccases by directed evolution. Biotechnol Bioeng 2012;109:297886.

Piscitelli A, Giardina P, Mazzoni C, Sannia G. Recombinant expression of Pleurotus ostreatus laccases in Kluyveromyces lactis and Saccharomyces cerevisiae. Appl Microbiol Biot 2005;69:428-39.

Piscitelli A, Pezzella C, Giardina P, Faraco V, Sania G. Heterologous laccase production and its role in industrial applications. Bioengineered 2010;1:252-62.

Pita M, Mate DM, Gonzalez-Perez D, Shleev S, Fernandez VM, Alcalde M et al. Bioelectrochemical oxidation of water. J Am Chem Soc 2014;136:58925.

Pourmir A, Johannes TW. Directed evolution: selection of the host microorganism. Comput Struct Biotechnol J 2012;2:e201209012.

Rasekh B, Khajeh K, Ranjbar B, Mollania N, Almasinia B, Tirandaz H. Protein engineering of laccase to enhance its activity and stability in the presence of organic solvents. Eng Life Sci 2014;14:442-8.

Record E, Punt PJ, Chamkha M, Labat M, van den Hondel CAMJJ, Asther M. Expression of the Pycnoporus cinnabarinus laccase gene in Aspergillus niger and characterization of the recombinant enzyme. Eur $\mathrm{J}$ Biochem 2002;269:602-9.

Reetz MT, Carballeira JD. Iterative saturation mutagenesis (ISM) for rapid directed evolution of functional enzymes. Nat Protoc 2007;2:891-903.

Reinhammar BRM. Oxidation-reduction potentials of the electron acceptors in laccases and stellacyanin. BBA-Bioenergetics 1972;275:245-59.

Reiss R, Ihssen J, Thony-Meyer L. Bacillus pumilus laccase: a heat stable enzyme with a wide substrate spectrum. BMC Biotechnol 2011;11:9.

Riva, S. Laccases: blue enzymes for green chemistry. Trends Biotechnol 2006;24:219-26.

Robert V, Mekmouche Y, Pailley PR, Tron T. Engineering laccases: in search for novel catalysts. Curr Genomics 2011;12:123-9.

Rodgers CJ, Blanford CF, Giddens SR, Skamnioti P, Armstrong FA, Gurr SJ. Designer laccases: a vogue for high-potential fungal enzymes? Trends Biotechnol 2010;28:63-72. 
Rodríguez E, Ruiz-Dueñas FJ, Kooistra R, Ram A, Martínez AT, Martínez MJ. Isolation of two laccase genes from the white-rot fungus Pleurotus eryngii and heterologous expression of the pel3 encoded protein. J Biotechnol 2008;134:9-19.

Ruijssenaars HJ, Hartmans S. A cloned Bacillus halodurans multicopper oxidase exhibiting alkaline laccase activity. Appl Microbiol Biotechnol 2004;65:177-82.

Sadhasivam S, Savitha S, Swaminathan K, Lin FH. Production, purification and characterization of mid-redox potential laccase from a newly isolated Trichoderma harzianum WL1. Process Biochem 2008;43:736-42.

Saloheimo M, Niku-Paavola ML. Heterologous production of a ligninolytic enzyme - expression of the Phlebia radiata laccase gene in Trichoderma reesei. Nat. Biotechnol. 1991;9:987-90.

Santhanam N, Vivanco JM, Decker SR, Reardon KF. Expression of industrially relevant laccases: prokaryotic style. Trends Biotechnol 2011;29:480-9.

Sayut DJ, Sun L. Creating designer laccases. ChemBiol 2010;24:918-920.

Schneider P, Caspersen MB, Mondorf K, Halkier T, Skov LK, Ostergaard PR et al. Characterization of a Coprinus cinereus laccase. Enzyme Microb Technol 1999;25:502-8.

Schneider KP, Gewessler U, Flock T, Heinzle A, Schenk V, Kaufmann F et al. Signal enhancement in polysaccharide based sensors for infections by incorporation of chemically modified laccase. New Biotechnol 2012;29:5029.

Sherif M, Waung D, Korbeci B, Mavisakalyan V, Flick R, Brown G et al. Biochemical studies of the multicopper oxidase (small laccase) from Streptomyces coelicolor using bioactive phytochemicals and site-directed mutagenesis. Microb Biotechnol 2013;6:588-97.

Shleev SV, Morozova O, Nikitina O, Gorshina ES, Rusinova T, Serezhenkov VA et al. Comparison of physico-chemical characteristics of four laccases from different basidiomycetes. Biochimie 2004;86:693-703.

Shleev S, Nikitina O, Christenson A, Reimann CT, Yaropolov AI, Ruzgas T et al. Characterization of two new multiforms of Trametes pubescens laccase. Bioorg Chem 2007;35:35-49.

Silva CS, Damas JM, Chen Z, Brissos V, Martins LO, Soares CM et al. The role of Asp116 in the reductive cleavage of dioxygen to water in CotA laccase: assistance during the proton-transfer mechanism. Acta Crystallogr D 2012;68:186-93. 
Singh G, Bhalla A, Kaur P, Capalash N, Sharma P. Laccase from prokaryotes: A new source for an old enzyme. Rev Environ Sci Biotechnol 2011;10:309-26.

Soden DM, O'Callaghan J, Dobson ADW. Molecular cloning of a laccase isozyme gene from Pleurotus sajor-caju and expression in the heterologous Pichia pastoris host. Microbiology 2002;148:4003-14.

Solomon EI, Sundaram UM, Machonkin TE. Multicopper oxidases and oxygenases. Chem Rev 1996;96:2563-605.

Sonoki T, Kajita S, Ikeda S, Uesugi M, Tatsumi K, Katayama Y et al. Transgenic tobacco expressing fungal laccase promotes the detoxification of environmental pollutants. Appl Microbiol Biot 2005;67:138-42.

Suzuki T, Endo K, Ito M, Tsujibo H, Miyamoto K, Inamori Y. A thermostable laccase from Streptomyces lavendulae REN-7: purification, characterization, nucleotide sequence, and expression. Biosci Biotech Bioch 2003;67:216775 .

Terrón MC, González T, Carbajo JM, Yagüe S, Arana-Cuenca A, Téllez A et al. Structural close-related aromatic compounds have different effects on laccase activity and on lcc gene expression in the ligninolytic fungus Trametes sp. I-62. Fungal Genet Biol 2004;41:954-62.

Theerachat M, Emond S, Cambon E, Bordes F, Marty A, Nicaud $\mathrm{J}$ et al. Engineering and production of laccase from Trametes versicolor in the yeast Yarrowia lipolytica. Bioresource Technol 2012;125:267-74.

Torres-Salas P, Mate DM, Ghazi I, Plou FJ, Ballesteros AO, Alcalde M. Widening the $\mathrm{pH}$ activity profile of a fungal laccase by directed evolution. ChemBioChem 2013;14:934-7.

Toscano MD, De Maria L, Lobedanz S, Østergaard LH. Optimization of a small laccase by active-site redesign. ChemBioChem 2013;14:1209-11.

Tracewell CA, Arnold FH. Directed enzyme evolution: climbing fitness peaks one amino acid at a time. Curr Opin Chem Biol 2009;13:3-9.

Wahleithner JA, Xu F, Brown KM, Brown SH, Golightly EJ, Halkier T et al. The identification and characterization of four laccases from the plant pathogenic fungus Rhizoctonia solani. Curr Genet 1996;29:395-403.

Wherland S, Farver O, Pecht, I. Multicopper oxidases: intramolecular electron transfer and $\mathrm{O}_{2}$ reduction. J Biol Inorg Chem. 2014;19:541-54.

Xu F. Catalysis of novel enzymatic iodide oxidation by fungal laccase. Appl Biochem Biotech 1996,59:221-30. 
Xu F, Berka RM, Wahleithner JA, Nelson BA, Shuster JR, Brown SH et al. Site-directed mutations in fungal laccase: effect on redox potential, activity and $\mathrm{pH}$ profile. Biochemical J 1998;334: 63-70.

Xu F, Palmer AE, Yaver DS, Berka RM, Gambetta GA, Brown SH, Solomon EI. Targeted mutations in a Trametes villosa laccase - Axial perturbations of the T1 copper. J Biol Chem 1999;274:12372-5.

Yaver DS, Overjero AI, Xu F, Nelson BA, Brown KM, Halkier T et al. Molecular characterization of laccase genes from the basidiomycete Coprinus cinereus and heterologous expression of the laccase Lcc1. Appl Environ Microbiol 1999;65:4943-8.

Ye M, Li G, Liang W, Liu Y. Molecular cloning and characterization of a novel metagenome-derived multicopper oxidase with alkaline laccase activity and highly soluble expression. Appl Microbiol Biotechnol 2010;87:1023-31.

Yoshida H. LXIII.-Chemistry of lacquer (Urushi). Part I. Communication from the Chemical Society of Tokio. J Chem Soc Trans 1883;43:472-86.

You LF, Liu ZM, Lin JF, Guo LQ, Huang XL, Yang HX. Molecular cloning of a laccase gene from Ganoderma lucidum and heterologous expression in Pichia pastoris. J Basic Microbiol 2014;54:S134-S141.

Zhao HM, Giver L, Shao ZX, Affholter JA, Arnold FH. Molecular evolution by staggered extension process (StEP) in vitro recombination. Nat Biotechnol 1998;16: 258-61.

Zsebo KM, Lu HS, Fieschko JC, Goldstein L, Davis J, Duker K et al. Protein secretion from Saccharomyces cerevisiae directed by the prepro-a-factor leader region. J Biol Chem 1986;261:5858-65.

Zumárraga M, Bulter T, Shleev S, Polaina J, Martínez-Arias A, Plou FJ et al. In vitro evolution of a fungal laccase in high concentrations of organic cosolvents. Chem Biol 2007;14:1052-64.

Zumárraga M, Domínguez CV, Camarero S, Shleev S, Polaina J, MartínezArias A. et al. Combinatorial saturation mutagenesis of the Myceliophthora thermophila laccase T2 mutant: the connection between the C-terminal plug and the conserved ${ }_{509} \mathrm{VSG}_{511}$ tripeptide. Comb Chem High $\mathrm{T}$ Scr 2008a;11:807-16.

Zumárraga M, Camarero S, Shleev S, Martínez-Arias A, Ballesteros A, Plou FJ et al. Altering the laccase functionality by in vivo assembly of mutant libraries with different mutational spectra. Proteins 2008b;71:250-60. 


\section{FIGURE LEGENDS}

Figure 1. General structure and details of the active site of laccase (Trametes trogii laccase, PDB ID: 2HRG). The three cupredoxin-like domains (D1, D2 and D3) are shown in green, cyan and magenta, respectively. Purple blue spheres represent copper ions and red spheres depict coordinating water molecules. The residues of the internal transfer pathway from T1 $\mathrm{Cu}$ to the T2/T3 trinuclear cluster are colored in yellow. Residues involved in the first coordination sphere of the catalytic coppers and their interactions (as black dashes) are also represented.

Figure 2. Artificial evolution pathways for functional secretion in $\mathbf{S}$. cerevisiae of HRPL (PM1L (A) and PcL, (B)). Mutational exchange between the two parallel evolution pathways is indicated by the red and blue shaded box for PM1L and PcL, respectively. The new point mutations are underlined. TAI: total activity improvement detected in $S$. cerevisiae microcultures for each mutant compared to the best parental type of the corresponding generation. TI: thermostability improvement in reference to the parental type of the corresponding generation. IVOE: in vivo overlap extension. IvAM: in vivo assembly of mutant libraries with different mutational spectra.

Figure 3. Laboratory evolution history of the PM1L. (A) Combination of directed evolution, site-directed mutagenesis (SDM) and saturation mutagenesis (SM) for functional expression in S. cerevisiae and blood tolerance. The a-factor pre-leader is represented in purple, the a-factor proleader is in pink, and the mature laccase is in cyan. The amino acid mutations responsible for secretion in S. cerevisiae and blood tolerance are depicted as yellow and red stars, respectively. Silent mutations are not included. (B) Model of ChU-B mutant. The copper ions are depicted as blue spheres. The amino acid substitutions responsible for functional expression in $S$. cerevisiae and blood tolerance are highlighted as yellow and red sticks, respectively. 
Figure 1

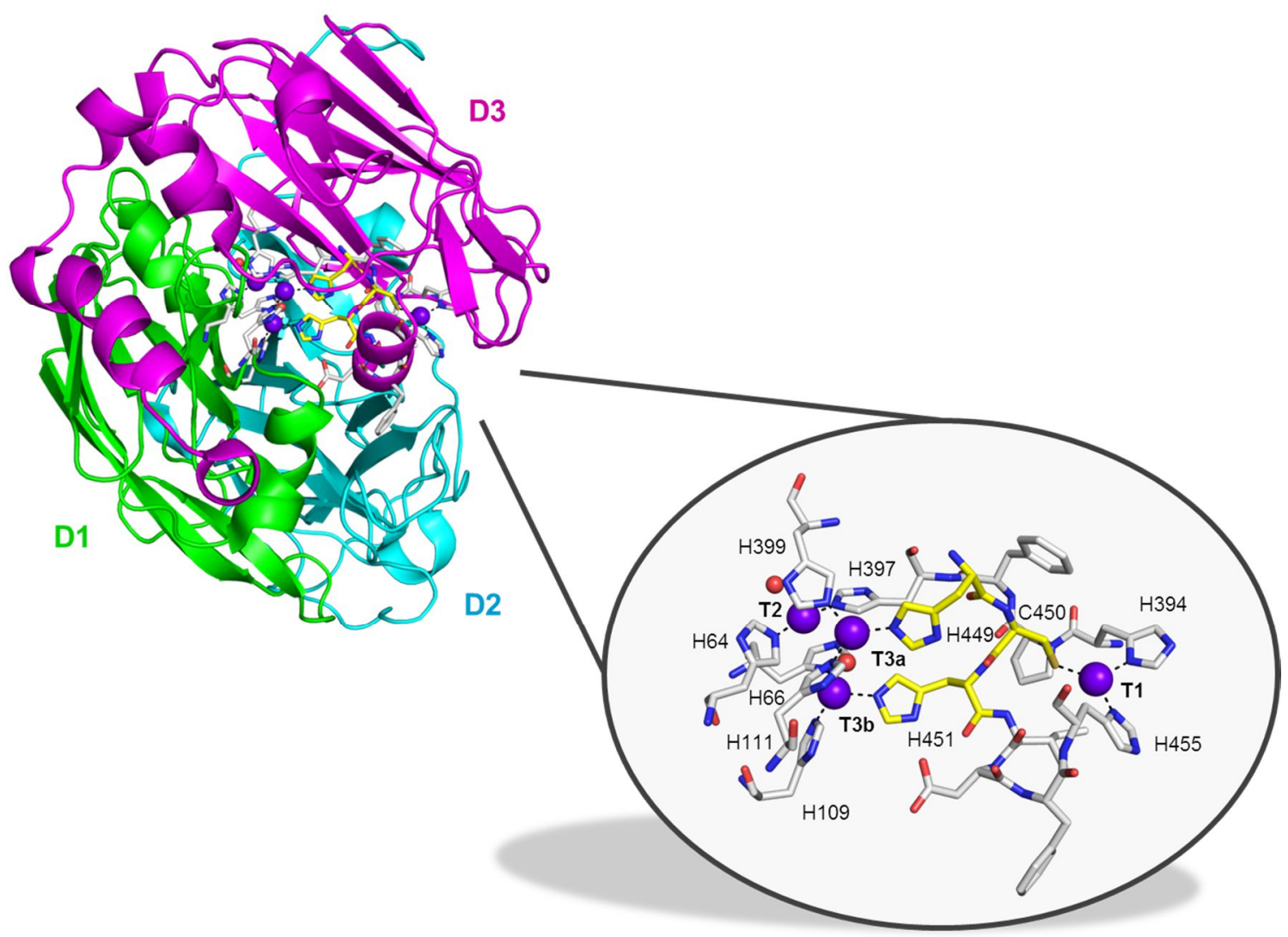




\section{Figure 2}

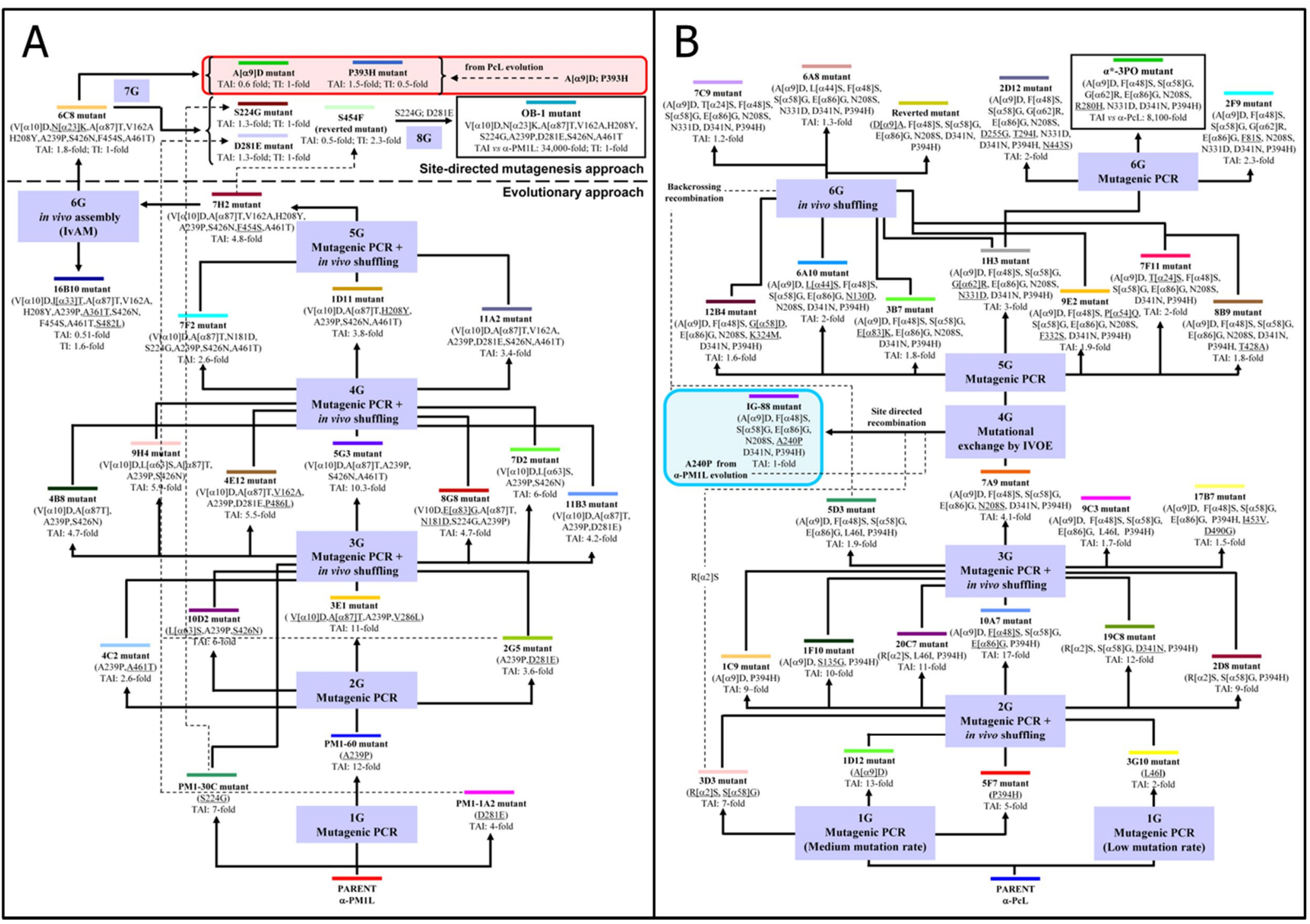




\section{Figure 3}

A

$\alpha-P M 1 L$

$\operatorname{pre} \alpha \quad \operatorname{pro} \alpha \quad$ Mature laccase

\section{Functional expression 7 rounds of directed evolution in S. cerevisiae and semi-rational approaches}

OB-1

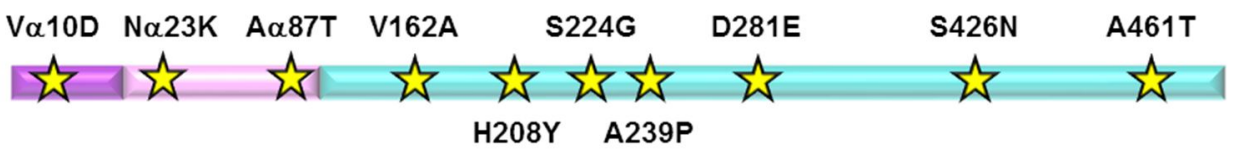

$\begin{array}{lllllll}\text { ChU-B V } & \text { S10D N } \alpha 23 K & \text { A } \alpha 87 T & \text { V162A S24G D281E F396IS426N A461T }\end{array}$

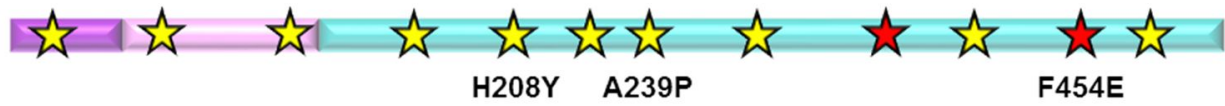

B

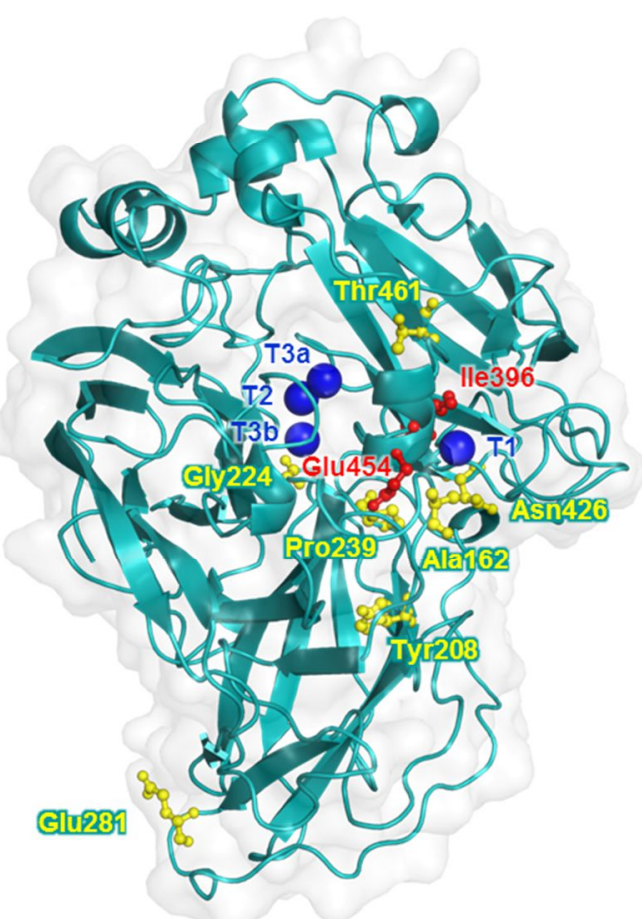


Table 1. Redox potential at the $\mathrm{T} 1$ site $\left(\mathrm{E}^{0^{\prime}} \mathrm{T}_{1}\right)$ of laccases from different organisms and the corresponding sequence alignments.

\begin{tabular}{|c|c|c|c|c|c|}
\hline Laccase source & Organism & Sequence source & $\mathrm{E}^{0}$ 'T1, mV (vs. NHE) & Sequence alignment & Reference \\
\hline \multicolumn{6}{|l|}{ HIGH REDOX POTENTIAL } \\
\hline Trametes ochracea & Basidiomycete & $\mathrm{PDB} 2 \mathrm{HZH}$ & $+790 \pm 10$ & ${ }^{452} H \underline{\mathrm{C}} H \mathrm{I} \mathrm{D} F \underline{\mathrm{H}} \mathrm{L} \mathrm{E} \mathrm{A} \mathrm{G} \underline{\mathbf{F}}^{463}$ & Shleev et al., 2004 \\
\hline Trametes trogii & Basidiomycete & PDB 2HRH & +790 & ${ }^{449} H \underline{\overline{\mathbf{C}}} H$ I D F $\underline{\overline{\mathrm{H}}} \mathrm{L}$ E A G $\underline{\overline{\mathbf{F}}}^{460}$ & Garzillo et al., 2001 \\
\hline Trametes versicolor & Basidiomycete & PDB 1GYC & +785 & ${ }^{452} H \underline{\overline{\mathrm{C}}} H$ I D F $\underline{\overline{\mathrm{H}}} \mathrm{L}$ E A G $\underline{\overline{\mathbf{F}}}^{463}$ & Reinhammar, 1972 \\
\hline Botrytis cinerea & Ascomycete & CCD45861.1 & +780 & ${ }^{508} H \underline{\mathrm{C}} H \mathrm{I}$ A W $\underline{\mathrm{H}}$ A S E G $\underline{\mathbf{L}}^{519}$ & Li et al., 1999 \\
\hline Coriolopsis fulvocinerea & Basidiomycete & n.d. & $+780 \pm 10$ & n.d. - & Shleev et al., 2004 \\
\hline Trametes hirsuta & Basidiomycete & AAA33103.1 & $+780 \pm 10$ & ${ }^{452} H \underline{\mathrm{C}} H \mathrm{I} \mathrm{D} F \underline{\mathrm{H}} \mathrm{L} \mathrm{D}$ A G $\underline{\mathbf{F}}^{463}$ & Shleev et al., 2004 \\
\hline Trametes villosa & Basidiomycete & AAC41686.1 & +780 & ${ }^{452} H \underline{\mathrm{C}} H$ I D F $\underline{\mathrm{H}} \mathrm{L} \mathrm{E}$ A G $\underline{\mathbf{F}}^{463}$ & Li et al., 1999 \\
\hline Basidiomycete PM1 & Basidiomycete & CAA78144.1 & +759 & ${ }^{449} H \underline{\overline{\mathrm{C}}} H \mathrm{I} \mathrm{D} F \underline{\overline{\mathrm{H}}} \mathrm{L} \mathrm{E}$ A G $\underline{\mathbf{F}}^{460}$ & Mate et al., 2013a \\
\hline Cerrena maxima & Basidiomycete & UP DOVWU3.1 & $+750 \pm 5$ & ${ }^{452} H \underline{\mathrm{C}} H$ I D F $\underline{\mathrm{H}} \mathrm{L}$ E G G $\underline{\mathbf{F}}^{463}$ & Shleev et al., 2004 \\
\hline Pycnoporus cinnabarinus & Basidiomycete & AAC39469.1 & +750 & ${ }^{450} H \overline{\mathrm{C}} H \mathrm{I} \mathrm{D} F \underline{\mathrm{H}} \mathrm{L} \mathrm{E}$ A G $\underline{\mathbf{F}}^{461}$ & Li et al., 1999 \\
\hline Trametes pubescens (LAC1) & Basidiomycete & AAM 18408.1 & $+746 \pm 5$ & ${ }^{457} H \underline{\mathrm{C}} H \mathrm{I} \mathrm{D} F \underline{\overline{\mathrm{H}}} \mathrm{L} \mathrm{E}$ A G $\underline{\overline{\mathbf{F}}}^{468}$ & Shleev et al., 2007 \\
\hline RL5 & Metagenomic & n.d. & +745 & n.d. & Beloqui et al., 2006 \\
\hline Pleurotus ostreatus (POXC) & Basidiomycete & PRF 1587216 & +740 & ${ }^{460} H \underline{\mathrm{C}} H \mathrm{I} \mathrm{D} \mathrm{W} \underline{\mathrm{H}} \mathrm{L} \mathrm{E}$ I G $\underline{\mathbf{L}}^{471}$ & Garzillo et al., 2001 \\
\hline Trametes pubescens (LAC2) & Basidiomycete & AAM 18407.1 & $+738 \pm 5$ & ${ }^{452} H \underline{\overline{\mathrm{C}}} H \mathrm{I} \mathrm{D} F \underline{\overline{\mathrm{H}}} \mathrm{L} \mathrm{E}$ A G $\underline{\overline{\mathbf{F}}}^{463}$ & Shleev et al., 2007 \\
\hline Trametes sp. C30 (LAC1) & Basidiomycete & AAF06967.1 & +730 & ${ }^{449} H \underline{\overline{\mathrm{C}}} H$ I D F $\underline{\overline{\mathrm{H}}} \mathrm{L}$ E A G $\underline{\mathbf{F}}^{460}$ & Klonowska et al., 2002 \\
\hline Botrytis aclada & Ascomycete & $\mathrm{AFC} 76164.1$ & +720 & ${ }^{525} H \underline{\overline{\mathbf{C}}} H \mathrm{I}$ A W $\underline{\underline{\mathrm{H}}}$ A S E G $\underline{\underline{\mathbf{L}}}^{536}$ & Osipov et al., 2014 \\
\hline \multicolumn{6}{|l|}{ MEDIUM REDOX POTENTIAL } \\
\hline Rhizoctonia solani & Basidiomycete & UP Q02081.1 & +710 & ${ }^{459} H \underline{\mathrm{C}} H \mathrm{I} \mathrm{D} \mathrm{W} \underline{\mathrm{H}} \mathrm{L} \mathrm{E}$ A G $\underline{\mathbf{L}}^{470}$ & Xu et al., 1998 \\
\hline Rigidoporus lignosus & Basidiomycete & PDB 1V10 & +700 & ${ }^{472} H \underline{\overline{\mathrm{C}}} H \mathrm{I} \mathrm{D} \mathrm{W} \underline{\mathrm{H}} \mathrm{L} \mathrm{E}$ A G $\underline{\mathbf{L}}^{483}$ & Bonomo et al., 1998 \\
\hline Trichoderma harzianum WL1 & Ascomycete & n.d. & +692 & n.d. & Sadhasivam et al., 2008 \\
\hline Pleurotus ostreatus (POXA1b) & Basidiomycete & CAA06292.1 & +650 & ${ }^{450} H \underline{\mathrm{C}} H \mathrm{I} \mathrm{D} \mathrm{W} \underline{\mathrm{H}} \mathrm{L} \mathrm{D} \mathrm{L}$ G $\underline{\mathbf{F}}^{461}$ & Garzillo et al., 2001 \\
\hline Trametes sp. C30 (LAC2) & Basidiomycete & AAM66348.1 & +560 & ${ }^{452} H \underline{\mathrm{C}} H \mathrm{I} \mathrm{D} F \underline{\mathrm{H}} \mathrm{L}$ E A G $\underline{\mathbf{F}}^{463}$ & Klonowska et al., 2002 \\
\hline Coprinus cinereus & Basidiomycete & PDB 1A65 & +550 & ${ }^{451} H \underline{\overline{\mathbf{C}}} H \mathrm{I}$ E F $\underline{\overline{\mathrm{H}}} \mathrm{L} \mathrm{M}$ N G $\underline{\overline{\mathbf{L}}}^{462}$ & Schneider et al., 1999 \\
\hline Trichophyton rubrum LKY-7 & Ascomycete & EGD86557.1 & +540 & ${ }^{530} H \underline{\overline{\mathrm{C}}} H \mathrm{I}$ A W $\underline{\overline{\mathrm{H}}} \mathrm{S} \mathrm{S}$ Q G $\underline{\overline{\mathbf{L}}}^{541}$ & Jung et al., 2002 \\
\hline Trametes sp. C30 (LAC3) & Basidiomycete & AAR00925.1 & +530 & ${ }^{452} H \underline{\overline{\mathrm{C}}} H$ I D F $\underline{\mathrm{H}} \mathrm{L} \mathrm{D}$ A G $\underline{\mathbf{F}}^{463}$ & Klonowska et al., 2005 \\
\hline CueO from Escherichia coli & Bacteria & PDB 2FQG & $+500^{\mathrm{a}}$ & ${ }^{471} H \underline{\overline{\mathrm{C}}} H \mathrm{LLE} \underline{\mathrm{H}} \mathrm{ED} \mathrm{T} \mathrm{G} \underline{\underline{\mathbf{M}}}^{482}$ & Miura et al., 2009 \\
\hline Scytalidium thermophilum & Ascomycete & Berka et al., 1995 & +510 & ${ }^{506} H \underline{\overline{\mathrm{C}}} \underline{\mathrm{H}}$ I A W $\underline{\overline{\mathrm{H}}}$ V S G G $\underline{\underline{\mathbf{L}}}^{517}$ & Xu et al., 1998 \\
\hline Melanocarpus albomyces & Ascomycete & PDB 1 GWO & +470 & ${ }^{502} H \underline{\mathrm{C}} H \mathrm{I}$ A W $\underline{\mathrm{H}}$ V S G G $\underline{\mathbf{L}}^{513}$ & Andberg et al., 2009 \\
\hline Myceliophthora thermophila & Ascomycete & ADA41449.1 & +470 & ${ }^{502} H \overline{\overline{\mathrm{C}}} H \mathrm{I}$ A W $\underline{\overline{\mathrm{H}}}$ V S G G $\overline{\mathbf{L}}^{513}$ & Xu et al., 1998 \\
\hline \multicolumn{6}{|l|}{ LOW REDOX POTENTIAL } \\
\hline CotA from Bacillus subtilis & Bacteria & PDB 1GSK & +455 & ${ }^{491} H \underline{\mathrm{C}} H \mathrm{I} \mathrm{L} \mathrm{E} \underline{\mathrm{H}} \mathrm{E} \mathrm{D}$ Y D $\underline{\mathbf{M}}^{502}$ & Melo et al., 2007 \\
\hline CueO from Escherichia coli & Bacteria & PDB 2FQG & $+440^{\mathrm{b}}$ & ${ }^{471} H \underline{\mathrm{C}} H \mathrm{LLE} \underline{\mathrm{H}} \mathrm{EDTC} \underline{\underline{\mathbf{M}}}^{482}$ & Miura et al., 2009 \\
\hline Rhus vernicifera & Plant & BAB63411.2 & +434 & ${ }^{495} H \underline{\mathrm{C}} H \mathrm{~F} \mathrm{E} \mathrm{R} \underline{\underline{\mathrm{H}}} \mathrm{T} \mathrm{T}$ E G $\underline{\underline{\mathbf{M}}}^{506}$ & Reinhammar, 1972 \\
\hline SLAC from Streptomyces coelicolor & Bacteria & UP Q9XAL8 & +430 & ${ }^{287} H \overline{\bar{C}} H \mathrm{~V}$ Q S $\underline{\bar{H}} \mathrm{~S} D \mathrm{M} G \underline{\mathbf{M}}^{298}$ & Gallaway et al., 2008 \\
\hline McoP from Pyrobaculum aerophilum & Bacteria & PDB 3AW5 & +398 & ${ }^{430} \mathrm{H} \overline{\mathrm{C}} \mathrm{H}$ N L E $\underline{\overline{\mathrm{H}}}$ E D G G $\overline{\mathbf{M}}^{441}$ & Fernandes et al., 2010 \\
\hline Ssl1 from Streptomyces sviceus & Bacteria & $\mathrm{PDB} 4 \mathrm{M} 3 \mathrm{H}$ & $+375 \pm 8$ & ${ }^{284} H \underline{\overline{\mathrm{C}}} H \mathrm{~V}$ Q S $\underline{\overline{\mathrm{H}}} \mathrm{S} \mathrm{D} \mathrm{M}$ G $\underline{\mathbf{M}}^{295}$ & Gunne et al., 2014 \\
\hline
\end{tabular}

The isoenzyme is in parentheses. The T3 $\mathrm{Cu}$ ligands are in italics, $\mathrm{T} 1 \mathrm{Cu}$ ligands are underlined and the T1 Cu axial ligand is in bold. Unless otherwise specified (PDB, Protein Data Bank, UP, UniProt database, PRF, Protein Research Foundation), the sequence codes are from GenBank. n.d.: sequence not deposited. ${ }^{\mathrm{E}} \mathrm{E}^{0}{ }_{\mathrm{T} 1}$ determined at $\mathrm{pH}$ 5.0. ${ }^{\mathrm{b}} \mathrm{E}^{\mathrm{0}}{ }_{\mathrm{T} 1}$ determined at $\mathrm{pH} 7.0$. 
Table 2. Bacterial laccases and multicopper oxidases heterologously expressed in bacteria (E. coli and Streptomyces lividans).

\begin{tabular}{|c|c|c|c|}
\hline Expression host & Laccase source & Expression yield* & Reference \\
\hline E. coli & Aquifex aeolicus VF5 (McoA) & n.r. & Fernandes et al., 2007 \\
\hline E. coli & Bacillus sp. HR03 (CotA) & n.r. & Mohammadian et al., 2010 \\
\hline E. coli & Bacillus clausii KSM-K16 (CotA) & n.r. & Brander et al., 2014 \\
\hline E. coli & Bacillus licheniformis DSM 13 (CotA) & $\begin{array}{l}410 \mathrm{U} / \mathrm{L} \text { and } 26 \mathrm{mg} / \mathrm{L} \text { for the wild-type (ABTS); 3,400 U/L } \\
\text { and } \sim 300 \mathrm{mg} / \mathrm{L} \text { for the K316N/D500G mutant (ABTS) }\end{array}$ & Koschorreck et al., 2009 \\
\hline E. coli & Bacillus halodurans & 2,600 U/L (SGZ), $400 \mathrm{U} / \mathrm{L}$ (ABTS) and $0.54 \mathrm{U} / \mathrm{L}$ (DMP) & Ruijssenaars and Hartmans, 2004 \\
\hline E. coli & Bacillus pumilus & n.r. & Reiss et al., 2011 \\
\hline E. coli & Bacillus subtilis (CotA) & n.r. & Martins et al., 2002 \\
\hline E. coli & $\begin{array}{l}\text { Lac15 from a metagenome library of } \\
\text { marine microbes }\end{array}$ & n.r. & Fang et al., 2011 \\
\hline E. coli & $\begin{array}{l}\text { Lac591 from a metagenome library of } \\
\text { mangrove soil microbes }\end{array}$ & 380 mg/L (guaiacol) & Ye et al., 2010 \\
\hline E. coli & $\begin{array}{l}\text { RL5 from a metagenome library of } \\
\text { bovine rumen microflora }\end{array}$ & n.r. & Beloqui et al., 2006 \\
\hline E. coli & Pyrobaculum aerophilum (McoP) & n.r. & Fernandes et al., 2010 \\
\hline E. coli & Streptomyces coelicolor M145 (SLAC) & n.r. & Machczynski et al., 2004 \\
\hline E. coli & Streptomyces griseus IFO 13350 (EpoA) & n.r. & Endo et al., 2003 \\
\hline E. coli & Streptomyces ipomoea CECT 3341 & n.r. & Molina-Guijarro et al., 2009 \\
\hline E. coli & Streptomyces lavendulae REN-7 & $76 \mathrm{U} / \mathrm{L}, 10 \mathrm{mg} / \mathrm{L}$ (catechol) & Suzuki et al., 2003 \\
\hline $\begin{array}{l}\text { Streptomyces } \\
\text { lividans }\end{array}$ & Streptomyces coelicolor A3(2) (SLAC) & 350 mg/L (ABTS) & Dubé et al., 2008 \\
\hline
\end{tabular}

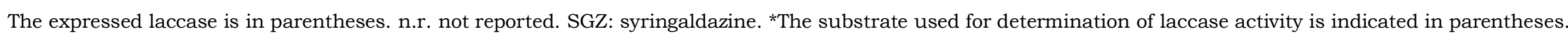


Table 3. Fungal laccases heterologously expressed in yeast (Kluyveromyces lactis, Pichia pastoris, Pichia methanolica, Saccharomyces cerevisiae and Yarrowia lipolytica).

\begin{tabular}{|c|c|c|c|c|}
\hline Expression host & Laccase source & Signal peptide (SP) used & Expression yield* & Reference \\
\hline K. lactis & Pleurotus ostreatus ${ }^{\mathrm{b}}$ (POXA1b) & Native SP & $2,030 \mathrm{U} / \mathrm{L}, 1.6 \mathrm{mg} / \mathrm{L}$ & Piscitelli et al., 2005 \\
\hline K. lactis & Pleurotus ostreatus ${ }^{\mathrm{b}}$ (POXC) & Native SP & $100 \mathrm{U} / \mathrm{L}, 1.9 \mathrm{mg} / \mathrm{L}$ & Piscitelli et al., 2005 \\
\hline P. pastoris & Botrytis aclada & Native SP & $53,300 \mathrm{U} / \mathrm{L}^{1}, 517 \mathrm{mg} / \mathrm{L}^{1}$ & Kittl et al., 2012a \\
\hline P. pastoris & Botrytis aclada & Native SP & $51,000 \mathrm{U} / \mathrm{L}^{2}, 495 \mathrm{mg} / \mathrm{L}^{2}$ & Kittl et al., 2012b \\
\hline P. pastoris & Ganoderma lucidum & Native SP & $686 \mathrm{U} / \mathrm{L}, 6 \mathrm{mg} / \mathrm{L}$ & You et al., 2014 \\
\hline P. pastoris & Pleurotus sajor-cajub & Native SP & $10,200 \mathrm{U} / \mathrm{L}, 4.85 \mathrm{mg} / \mathrm{L}$ & Soden et al., 2002 \\
\hline P. pastoris & Pycnoporus cinnabarinus ${ }^{\mathrm{b}}$ & Native SP / S. cerevisiae a-factor prepro-leader & $8 \mathrm{mg} / \mathrm{L}$ & Otterbein et al., 2000 \\
\hline P. pastoris & Pycnoporus coccineus ${ }^{\mathrm{b}}$ & Native SP / S. cerevisiae a-factor prepro-leader & Solid phase & Hoshida et al., 2001 \\
\hline P. pastoris & Fomes lignosus ${ }^{\mathrm{b}}$ & Native SP & $9,030 \mathrm{U} / \mathrm{L}, 144 \mathrm{mg} / \mathrm{L}$ & Liu et al., 2003; Hu et al., 2007 \\
\hline P. pastoris & Trametes sanguinea M85-2 & Native SP & Solid phase & Hoshida et al., 2001 \\
\hline P. pastoris & Trametes sp. $420^{b}$ & S. cerevisiae a-factor prepro-leader & 239,000 U/L, $136 \mathrm{mg} / \mathrm{L}$ & Cui et al., 2007 \\
\hline P. pastoris & Trametes sp. AH28-2b (LacB) & S. cerevisiae a-factor prepro-leader & $32,000 \mathrm{U} / \mathrm{L}, 31.6 \mathrm{mg} / \mathrm{L}$ & Li et al., 2007 \\
\hline P. pastoris & Trametes trogii ${ }^{\mathrm{b}}$ & SP nativo & $2,520 \mathrm{U} / \mathrm{L}, 17 \mathrm{mg} / \mathrm{L}$ & Colao et al., 2006 \\
\hline P. pastoris & Trametes versicolor & SP nativo & $140,000 \mathrm{U} / \mathrm{L}$ & Hong et al., 2002 \\
\hline P. methanolica & Trametes versicolor & S. cerevisiae a-factor prepro-leader & $12,600 \mathrm{U} / \mathrm{L}$ & Guo et al., 2006 \\
\hline S. cerevisiae & Melanocarpus albomycesa & S. cerevisiae a-factor prepro-leader & $270 \mathrm{U} / \mathrm{L}, 7.4 \mathrm{mg} / \mathrm{L}$ & Andberg et al., 2009 \\
\hline S. cerevisiae & Myceliophthora thermophila ${ }^{\mathrm{a}}$ & S. cerevisiae a-factor prepro-leader & $18 \mathrm{mg} / \mathrm{L}$ & Bulter et al., 2003 \\
\hline S. cerevisiae & Pleurotus eryngi ${ }^{\mathrm{b}}$ & Native SP & $146 \mathrm{U} / \mathrm{L}$ & Bleve et al., 2008 \\
\hline S. cerevisiae & Pleurotus ostreatus (POXA1b) & Native SP & $200 \mathrm{U} / \mathrm{L}$ & Piscitelli et al., 2005 \\
\hline S. cerevisiae & Basidiomycete PM1b & S. cerevisiae a-factor prepro-leader & $\sim 8 \mathrm{mg} / \mathrm{L}$ & Maté et al., 2010 \\
\hline S. cerevisiae & Pycnoporus cinnabarinus ${ }^{\mathrm{b}}$ & S. cerevisiae a-factor prepro-leader & $300 \mathrm{U} / \mathrm{L}, \sim 2 \mathrm{mg} / \mathrm{L}$ & Camarero et al., 2012 \\
\hline S. cerevisiae & Pycnoporus coccineus ${ }^{\mathrm{b}}$ & Native SP & Solid phase & Hoshida et al., 2005 \\
\hline S. cerevisiae & Trametes sanguínea M85-2 & Native SP & Solid phase & Hoshida et al., 2001 \\
\hline S. cerevisiae & Trametes sp. C30b (LAC3) & S. cerevisiae invertase SP & $2 \mathrm{mg} / \mathrm{L}$ & Klonowska et al., 2005 \\
\hline S. cerevisiae & Trametes hirsuta $\mathrm{b}$ & Native SP & Solid phase & Kojima et al., 1990 \\
\hline Y. lipolytica & Pycnoporus cinnabarinus ${ }^{b}$ & Y. lipolytica XPR2 prepro-sequence & 1,026 U/L, $19.8 \mathrm{mg} / \mathrm{L}$ & Madzak et al., 2005 \\
\hline Y. lipolytica & Trametes versicolor (Laccase IIIb) & Native SP & $230 \mathrm{U} / \mathrm{L}, 2.5 \mathrm{mg} / \mathrm{L}$ & Jolivalt et al., 2005 \\
\hline Y. lipolytica & Trametes versicolor (Lcc1) & Native SP & $250 \mathrm{U} / \mathrm{L}^{3}, 1,000 \mathrm{U} / \mathrm{L}^{4}$ & Theerachat et al., 2012 \\
\hline
\end{tabular}

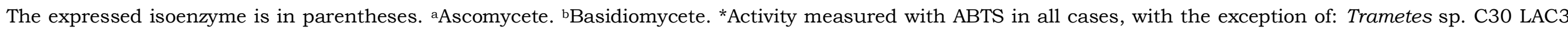

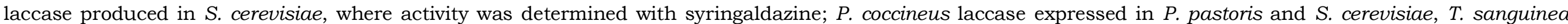

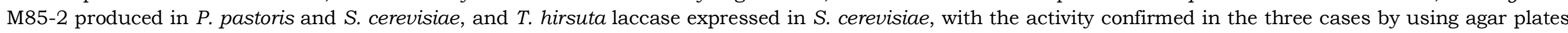

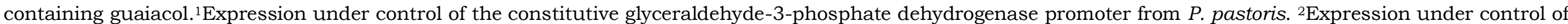

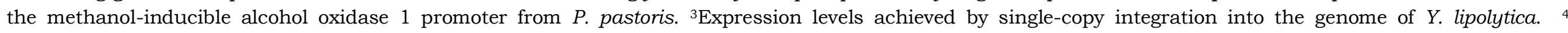
Expression levels achieved by multiple-copy integration into the genome of $Y$. lipolytica. 
Table 4. Fungal laccases heterologously expressed in filamentous fungi (Aspergillus nidulans, Aspergillus niger, Aspergillus oryzae, Penicillium canescens and Trichoderma reesei), plants (Nicotiana tabacum, Oryza sativa and Zea mays) and bacteria (Escherichia coli).

\begin{tabular}{|c|c|c|c|c|}
\hline Expression host & Laccase source & Signal peptide (SP) used & Expression yield* & Reference \\
\hline A. nidulans & Ceriporiopsis subvermispora (Lcs-1) & Native SP & $200 \mathrm{U} / \mathrm{L}$ & Larrondo et al., 2003 \\
\hline A. niger & Ceriporiopsis subvermispora (Lcs-1) & Native SP & $200 \mathrm{U} / \mathrm{L}$ & Larrondo et al., 2003 \\
\hline A. niger & Phanerochaete flavido-alba & A. niger glucoamylase SP & $2,500 \mathrm{U} / \mathrm{L}, 30 \mathrm{mg} / \mathrm{L}$ & Benghazi et al., 2013 \\
\hline A. niger & Pleurotus eryngii (PEL3) & A. niger glucoamylase SP & $2.4 \mathrm{U} / \mathrm{mg}$ protein & Rodriguez et al., 2008 \\
\hline A. niger & Pleurotus ostreatus ${ }^{\mathrm{b}}$ (POXA1b) & A. niger glucoamylase SP & $60,000 \mathrm{U} / \mathrm{L}, 20 \mathrm{mg} / \mathrm{L}$ & Macellaro et al., 2014 \\
\hline A. niger & Pycnoporus cinnabarinus ${ }^{\mathrm{b}}$ & A. niger glucoamylase SP & $7,000 \mathrm{U} / \mathrm{L}, 70 \mathrm{mg} / \mathrm{L}$ & Record et al., 2002 \\
\hline A. niger & Trametes sp. C30b (LAC3) & A. niger glucoamylase SP & $42,000 \mathrm{U} / \mathrm{L}, 840 \mathrm{mg} / \mathrm{L}$ & Mekmouche et al., 2014 \\
\hline A. niger & Trametes versicolor & Native SP & $2,700 \mathrm{U} / \mathrm{L}$ & Bohlin et al., 2006 \\
\hline A. oryzae & Coprinus cinereusb (Lcc1) & Native SP & $135 \mathrm{mg} / \mathrm{L}$ & Yaver et al., 1999 \\
\hline A. oryzae & Myceliophthora thermophila & Native SP & $850 \mathrm{U} / \mathrm{L}, 19 \mathrm{mg} / \mathrm{L}$ & Berka et al., 1997 \\
\hline A. oryzae & Rhizoctonia solani ${ }^{\mathrm{b}}$ & Native SP & n.d. & Wahleithner et al., 1996 \\
\hline A. oryzae & Pycnoporus coccineus ${ }^{\mathrm{b}}$ & Native SP & $3,000 \mathrm{U} / \mathrm{L}$ & Hoshida et al., 2005 \\
\hline P. canescens & Trametes hirsuta ${ }^{\mathrm{b}}$ & P. canescens $\beta$-galactosidase SP & $3,000 \mathrm{U} / \mathrm{L}$ & Abyanova et al., 2010 \\
\hline T. reesei & Melanocarpus albomycesa & Native SP & $46,800 \mathrm{U} / \mathrm{L}, 920 \mathrm{mg} / \mathrm{L}$ & Kiiskinen et al., 2004 \\
\hline T. reesei & Phlebia radiata ${ }^{\mathrm{b}}$ & Native SP & $462 \mathrm{U} / \mathrm{L}, 19.5 \mathrm{mg} / \mathrm{L}$ & Saloheimo and Niku-Paavola, 1991 \\
\hline T. reesei & Trametes versicolor & T. reesei cellobiohydrolase I SP & $800-1,000 \mathrm{mg} / \mathrm{L}$ & Baker and White, 2001 \\
\hline N. tabacum & Schizophyllum commune & Native SP & $0.79 \mathrm{U} / \mathrm{g}$ dry weight & Hirai et al., 2008 \\
\hline N. tabacum & Trametes versicolor & Native SP & n.r. & Sonoki et al., 2005 \\
\hline O. sativa & Melanocarpus albomycesa & O. sativa glutelin $\mathrm{B} 1 \mathrm{SP}$ & 13 ppm & de Wilde et al., 2008 \\
\hline O. sativa & Pycnoporus cinnabarinus ${ }^{b}$ & O. sativa glutelin $\mathrm{B} 1 \mathrm{SP}$ & 39 ppm & de Wilde et al., 2008 \\
\hline Z. mays & Trametes versicolor & Hordeum vulgare a-amylase SP & $>50 \mathrm{ppm}$ & Bailey et al., 2004 \\
\hline E. coli & Cyathus bullerib & Native SP & n.r. & Garg et al., 2008 \\
\hline
\end{tabular}

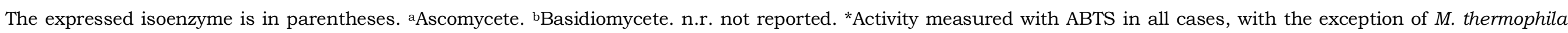

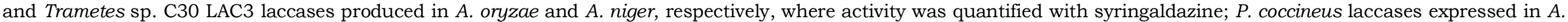

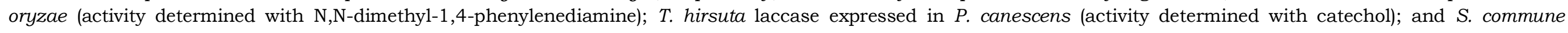
laccase produced in $N$. tabacum (activity measured with DMP). 
Table 5. Laccases engineered by site-directed mutagenesis.

\section{Laccase source}

CotA from Bacillus subtilis

Property in study

$\mathrm{E}^{\mathrm{O}} \mathrm{T} 1 \mathrm{and}$ catalytic efficiency

Bacillus sp. HR03

Thermal stability

Bacillus sp. HR03

CueO from Escherichia coli

CueO from Escherichia coli

SLAC from Streptomyces coelicolor

SLAC from Streptomyces coelicolor

SLAC from Streptomyces

coelicolor

Ss11 from Streptomyces sviceus

Myceliophthora thermophila

Rhizoctonia solani

Trametes villosa

Melanocarpus albomyces

Melanocarpus albomyces

Trametes versicolor

Trametes versicolor

Botrytis aclada

Organic solvent tolerance

$\mathrm{E}^{0}$ ' 1 and catalytic efficiency

$\mathrm{E}^{0}$ 'T1 and catalytic efficiency

Role of Tyr108 in the catalytic mechanism

Redesign of the putative substrate binding pocket

Activity

$\mathrm{E}^{0}$ ' 1 and catalytic efficiency

$\mathrm{E}^{0}{ }_{\mathrm{T} 1}$ and catalytic efficiency

$\mathrm{E}^{0}$ 'T1 and catalytic efficiency

$\mathrm{E}^{0}$ 'T1 and catalytic efficiency

Role of Glu235 in laccase catalysis

Role of the C-terminus in laccase catalysis

Catalytic efficiency toward phenolic and non-phenolic compounds

Catalytic efficiency toward bulky phenolic compounds

\section{Characterization}

Redox titration, EPR, CAAa

CD spectroscopy, intrinsic fluorescence analysis, CAAa

Colorimetric assays

Role of Leu499 in the overall structure and redox potential

Absorption spectroscopy CAA

$\mathrm{CAA}^{\mathrm{a}}$

$\mathrm{CAA}^{\mathrm{a}}$

Redox titration, $\mathrm{CAA}^{\mathrm{a}}$

Redox titration, EPR, $\mathrm{CAA}^{\mathrm{a}}$

Redox titration, EPR, CAA ${ }^{a}$

Redox titration, EPR, CAA

CD spectroscopy, redox

titration, mass spectrometry, $\mathrm{CAA}^{\mathrm{a}}$

CD spectroscopy, redox titration, CAA

HPLC and HPSEC analysis,

$\mathrm{CAA}^{\mathrm{a}}$

GC and HPLC analysis, CAA

Redox titration, CAA ${ }^{\mathrm{a}}$
Main results*

Increase of $\mathrm{E}^{0}{ }^{\prime} \mathrm{T} 1$ by $\sim 100 \mathrm{mV}$ and decrease in the catalytic efficiency

3 -fold higher thermal activation and $3^{\circ} \mathrm{C}$ higher $\mathrm{T}_{50} \mathrm{~b}$

Increase in $\mathrm{C}_{50^{c}}$ and decrease in thermoinactivation rates in the presence of organic solvents

Significant variations in $\mathrm{E}^{0^{\prime}} \mathrm{T} 1$ and activity compared to the wild-type

$\mathrm{E}^{0}$ 'T1 between $150 \mathrm{mV}$ lower and $100 \mathrm{mV}$ higher than the wild-type, catalytic efficiencies up to 140 fold higher

2.5-fold lower turnover numbers for $\mathrm{Y} 108 \mathrm{~F}$ and Y108A mutants

Higher catalytic efficiencies for DMP and better mediated-decolorization of indigo carmine

Determination of amino acid residues important for activity

Improved $\mathrm{E}^{0}{ }_{\mathrm{T} 1}$, lower kinetic constants

Reference

Durão et al., 2006, 2008

Mollania et al., 2011

Rasekh et al., 2014

Kurose et al., 2009

Kataoka et al., 2013

Structural perturbation at the $\mathrm{T} 1 \mathrm{Cu}$ and important changes in the catalytic efficiencies Structural perturbation at the $\mathrm{T} 1 \mathrm{Cu}$ and important changes in the catalytic efficiencies

F463M mutant showed a decrease of $0.1 \mathrm{~V}$ in the $\mathrm{E}^{0}{ }_{\mathrm{T} 1}$, altered EPR and UV-visible spectra, higher $k c a t$ and $\mathrm{Km}$ values and a more basic optimal $\mathrm{pH}$

D235T variant preferred DMP over ABTS and showed $\mathrm{pH}$ activity profiles for phenolic substrates significantly altered

Mutations in the C-terminal resulted in significan decrease on the laccase secretion levels in T. reese and $S$. cerevisiae

3 -fold increase in $k_{\text {cat }}$ for ABTS and the optimal pH for DMP was increased 1.4 units

Gupta et al., 2012

Toscano et al., 2013

Sherif et al., 2013

Gunne et al., 2014

Xu et al., 1998; Palmer et al., 2003

Xu et al., 1998

Xu et al., 1999

Kallio et al., 2009

Andberg et al., 2009

Madzak et al., 2006

Diverse results in function of the mutations tested

Galli et al., 2011

No significant changes in the overall structure;

$\mathrm{E}^{0}$ 'T1 $140 \mathrm{mV}$ lower than that from the wild-type; Osipov et al., 2014 higher $K_{m}$ values both for ABTS and DMP

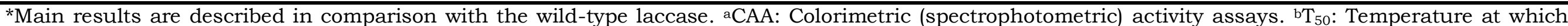

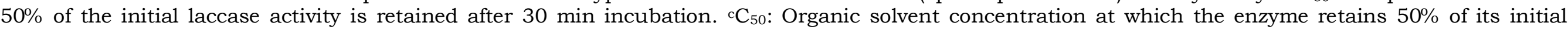
activity (i.e. activity in the absence of co-solvent). 
Table 6. Laccases engineered by saturation mutagenesis (SM), combinatorial saturation mutagenesis (CSM) and directed evolution.

\begin{tabular}{|c|c|c|c|c|c|}
\hline Laccase source & Approach & Property in study & $\begin{array}{l}\text { Characterization } \\
\text { techniques }\end{array}$ & Main results* & Reference \\
\hline $\begin{array}{l}\text { CotA from Bacillus } \\
\text { subtilis }\end{array}$ & $\mathrm{SM}$ & $\begin{array}{l}\text { Mechanism of } \\
\text { reduction of } \mathrm{O}_{2} \text { to } \\
\text { water }\end{array}$ & $\begin{array}{l}\text { Redox titration, EPR, } \\
\text { CD spectroscopy, CAA a }\end{array}$ & $\begin{array}{l}\text { Small changes in the geometry of the } \mathrm{Cu} \\
\text { sites. Turnover rates highly reduced and } \\
\text { optimal pH downshifted } 1-2 \text { units }\end{array}$ & Brissos et al., 2012 \\
\hline $\begin{array}{l}\text { CotA from Bacillus } \\
\text { subtilis }\end{array}$ & $\mathrm{SM}$ & $\begin{array}{l}\text { Mechanism of } \\
\text { reduction of } \mathrm{O}_{2} \text { to }\end{array}$ & Simulated pH titrations & $\begin{array}{l}\text { Asp } 116 \text { appears to be crucial in modulating } \\
\text { Glu498 protonation }\end{array}$ & Silva et al., 2012 \\
\hline $\begin{array}{l}\text { CotA from Bacillus } \\
\text { subtilis }\end{array}$ & CSM & Substrate specificity & $\mathrm{CAA}^{\mathrm{a}}$ & $\begin{array}{l}\text { The CotA-ABTS-10 mutant was } 132 \text {-fold } \\
\text { more specific for ABTS }\end{array}$ & Gupta et al., 2010 \\
\hline $\begin{array}{l}\text { Myceliophthora } \\
\text { thermophila }\end{array}$ & CSM & Catalytic efficiency & $\mathrm{CAA}^{\mathrm{a}}$ & $\begin{array}{l}\text { 3- and 8-fold higher catalytic efficiencies for } \\
\text { phenolic and non-phenolic compounds }\end{array}$ & $\begin{array}{l}\text { Zumárraga et al., } \\
\text { 2008a }\end{array}$ \\
\hline $\begin{array}{l}\text { CotA from Bacillus } \\
\text { licheniformis }\end{array}$ & Directed evolution & $\begin{array}{l}\text { Functional expression } \\
\text { in E. coli }\end{array}$ & $\mathrm{CAA}^{\mathrm{a}}$ & $\begin{array}{l}\text { K316N/D500G mutant showed 11.4-fold } \\
\text { higher expression levels }\end{array}$ & $\begin{array}{l}\text { Koschorreck et al., } \\
2009\end{array}$ \\
\hline $\begin{array}{l}\text { Lac591 } \\
\text { (metagenomic) }\end{array}$ & Directed evolution & $\begin{array}{l}\text { Efficiency in textile } \\
\text { dyes decolorization }\end{array}$ & $\mathrm{CAA}^{\mathrm{a}}$ & $\begin{array}{l}\text { 4.8-fold increased specific activity for DMP. } \\
\text { Higher decolorization efficiency for several }\end{array}$ & Liu et al., 2011 \\
\hline $\begin{array}{l}\text { CotA from Bacillus } \\
\text { subtilis }\end{array}$ & Directed evolution & Substrate specificity & $\begin{array}{l}\text { Bacterial surface } \\
\text { display }\end{array}$ & $\begin{array}{l}\text { The CotA-ABTS-SD } 1 \text { mutant was } 120 \text {-fold } \\
\text { more specific for ABTS }\end{array}$ & Gupta et al., 2010 \\
\hline $\begin{array}{l}\text { Myceliophthora } \\
\text { thermophila }\end{array}$ & Directed evolution & $\begin{array}{l}\text { Functional expression } \\
\text { in } S . \text { cerevisiae }\end{array}$ & $\mathrm{CAA}^{\mathrm{a}}$ & $\begin{array}{l}\text { Expression levels in } S \text {. cerevisiae of } 18 \mathrm{mg} / \mathrm{L} \\
\text { (T2 mutant) }\end{array}$ & Bulter et al., 2003 \\
\hline Basidiomycete PM1 & Directed evolution & $\begin{array}{l}\text { Functional expression } \\
\text { in } S . \text { cerevisiae }\end{array}$ & $\mathrm{CAA}^{\mathrm{a}}$ & $\begin{array}{l}\text { Expression levels in } S \text {. cerevisiae of } \sim 8 \mathrm{mg} / \mathrm{L} \\
\text { (OB-1 mutant) }\end{array}$ & Maté et al., 2010 \\
\hline $\begin{array}{l}\text { Pycnoporus } \\
\text { cinnabarinus }\end{array}$ & Directed evolution & $\begin{array}{l}\text { Functional expression } \\
\text { in S. cerevisiae }\end{array}$ & $\mathrm{CAA}^{\mathrm{a}}$ & $\begin{array}{l}\text { Expression levels in } S \text {. cerevisiae of } \sim 2 \mathrm{mg} / \mathrm{L} \\
\text { (3PO mutant) }\end{array}$ & Camarero et al., 2012 \\
\hline Pleurotus ostreatus & Directed evolution & Activity in S. cerevisiae & $\begin{array}{l}\text { CAA }^{\mathrm{a}} \text {, molecular } \\
\text { dynamics }\end{array}$ & $\begin{array}{l}\text { Mutants with enhanced specific activity } \\
\text { and/or improved stability }\end{array}$ & Festa et al., 2008 \\
\hline Pleurotus ostreatus & Directed evolution & Activity in $S$. cerevisiae & $\mathrm{CAA}^{\mathrm{a}}$ & $\begin{array}{l}\text { Mutants with enhanced specific activity } \\
\text { and/or improved stability }\end{array}$ & Miele et al., 2010a,b \\
\hline $\begin{array}{l}\text { Trametes versicolor } \\
\text { (Lcc1) }\end{array}$ & Directed evolution & Activity in $Y$. lipolytica & $\mathrm{CAA}^{\mathrm{a}}$ & $\begin{array}{l}\text { 5.8-fold increase in total activity (rM-4A } \\
\text { mutant) }\end{array}$ & Theerachat et al., 2012 \\
\hline Fomes lignosus & Directed evolution & Activity in $P$. pastoris & $\mathrm{CAA}^{\mathrm{a}}$ & $\begin{array}{l}\text { Expression levels in } P . \text { pastoris of } 144 \mathrm{mg} / \mathrm{L} \\
\text { (PPM5 mutant) }\end{array}$ & Hu et al., 2007 \\
\hline $\begin{array}{l}\text { Myceliophthora } \\
\text { thermophila }\end{array}$ & Directed evolution & $\begin{array}{l}\text { Organic solvent } \\
\text { tolerance }\end{array}$ & $\begin{array}{l}\text { redox titration, EPR, } \\
\text { cyclic voltammetry, } \\
\text { CAA }^{\text {a }}\end{array}$ & $\begin{array}{llcc}\text { Remarkable } & \text { resistance } & \text { to } & \text { high } \\
\text { concentrations } & \text { of organic } & \text { solvents } & \text { (R2 } \\
\text { mutant) } & & & \end{array}$ & Zumárraga et al., 2007 \\
\hline $\begin{array}{l}\text { Myceliophthora } \\
\text { thermophila }\end{array}$ & Directed evolution & Activity at alkaline $\mathrm{pH}$ & $\mathrm{CAA}^{\mathrm{a}}$ & $\begin{array}{l}\mathrm{pH} \text { activity profiles widely shifted toward } \\
\text { alkaline } \mathrm{pH} \text { values (IG-88 mutant) }\end{array}$ & $\begin{array}{l}\text { Torres-Salas et al., } \\
2013\end{array}$ \\
\hline Basidiomycete PM1 & Directed evolution & Blood tolerance & $\begin{array}{l}\text { CAA }^{\mathrm{a}} \text {, cyclic } \\
\text { voltammetry }\end{array}$ & $\begin{array}{l}\text { Activity in human blood and plasma (ChU-B } \\
\text { mutant) }\end{array}$ & Mate et al., 2013b \\
\hline $\begin{array}{l}\text { Trametes versicolor } \\
\text { (Lcc } 2)\end{array}$ & Directed evolution & Ionic liquid tolerance & $\mathrm{CAA}^{\mathrm{a}}$ & 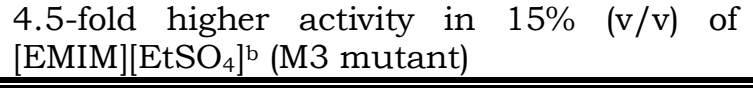 & Liu et al., 2013 \\
\hline
\end{tabular}

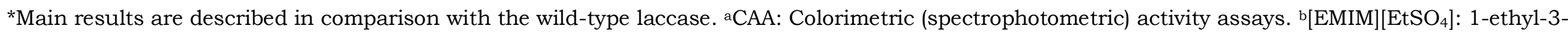
methylimidazolium ethyl sulfate. 
Table 7. Chimeric laccases.

\begin{tabular}{|c|c|c|c|c|}
\hline Parental types & $\begin{array}{l}\text { Sequence } \\
\text { identity }\end{array}$ & $\begin{array}{l}\text { Heterologous } \\
\text { host }\end{array}$ & Main results & Reference \\
\hline $\begin{array}{l}\text { Lcc } 1 \text { and Lcc } 4 \\
\text { from Lentinula } \\
\text { edodes }\end{array}$ & $60 \%$ & $\begin{array}{l}\text { Tobacco BY-2 } \\
\text { cells }\end{array}$ & $\begin{array}{l}\text { Chimeric laccases with similar } \\
\text { expression levels than Lcc1, } K_{m} \\
\text { values similar to those of Lcc4 and } \\
\text { pH and temperature profiles } \\
\text { intermediate between those of both }\end{array}$ & $\begin{array}{l}\text { Nakagawa et } \\
\text { al., } 2010\end{array}$ \\
\hline $\begin{array}{l}\text { LAC } 1, \text { LAC2, } \\
\text { LAC3 and LAC5 } \\
\text { from Trametes } \\
\text { sp. C30 }\end{array}$ & $65-71 \%$ & S. cerevisiae & $\begin{array}{l}\text { Chimeric laccases with similar } \\
\text { apparent kinetic parameters at acidic } \\
\text { pH than those for LAC3. LAC131 and } \\
\text { LAC232 chimeras exhibited higher } \\
\text { tolerance to alkaline pH than LAC3 }\end{array}$ & $\begin{array}{l}\text { Cusano et } \\
\text { al., } 2009\end{array}$ \\
\hline $\begin{array}{l}\text { OB- } 1 \text { and } 3 P O \\
\text { mutants }\end{array}$ & $76 \%$ & S. cerevisiae & $\begin{array}{l}\text { Chimeric laccases with combined } \\
\text { characteristics in terms of pH } \\
\text { activity, substrate affinity and } \\
\text { thermal stability }\end{array}$ & $\begin{array}{l}\text { Pardo et al., } \\
2012\end{array}$ \\
\hline $\begin{array}{l}\text { Ery4 and Ery3 } \\
\text { from Pleurotus } \\
\text { eryngii }\end{array}$ & n.r. & S. cerevisiae & $\begin{array}{l}\text { The 4NC3 chimera showed the } \\
\text { highest enzymatic activities, } \\
\text { substrate affinities and stability over } \\
\text { a broad pH and temperature range. It } \\
\text { was also successfully displayed on } \\
\text { the cell wall of } S \text {. cerevisiae }\end{array}$ & $\begin{array}{l}\text { Bleve et al., } \\
2014\end{array}$ \\
\hline
\end{tabular}

aOB-1 and 3PO are, respectively, the final mutants of the directed evolution campaigns of PM1 and P. cinnabarinus laccases for expression in S. cerevisiae (Mate et al., 2013b; Camarero et al., 2012). n.r. not reported. 